NBER WORKING PAPER SERIES

\title{
WHY HAS THE YEN FAILED TO BECOME A DOMINANT INVOICING CURRENCY IN ASIA? A FIRM-LEVEL ANALYSIS OF JAPANESE EXPORTERS' INVOICING BEHAVIOR
}

Takatoshi Ito Satoshi Koibuchi

Kiyotaka Sato

Junko Shimizu

Working Paper 16231

http://www.nber.org/papers/w16231

\author{
NATIONAL BUREAU OF ECONOMIC RESEARCH \\ 1050 Massachusetts Avenue \\ Cambridge, MA 02138 \\ July 2010
}

This study is supported by the Research Institute of Economy, Trade and Industry (RIETI) and the Ministry of Economy, Trade and Industry (METI). We wish to thank Masahiko Ozaki, Eiji Ogawa, Fukunari Kimura, Yuri Sasaki, Etsuro Shioji, and Kentaro Kawasaki for their supports on our interview research. We are grateful to Yusuke Naito, Kazunobu Hayakawa and Taiyo Yoshimi for their capable research assistance. We also thank Linda Goldberg, David Weinstein, Rebecca Hellerstein, Paolo Pesenti, Hugh Patrick, Shin-ichi Fukuda, Yuko Hashimoto, Robert Dekle, Masahiro Enya, Masanori Ono, and Zhang Zhiwei for their helpful comments on the earlier version of this paper. The views expressed herein are those of the authors and do not necessarily reflect the views of the National Bureau of Economic Research.

NBER working papers are circulated for discussion and comment purposes. They have not been peerreviewed or been subject to the review by the NBER Board of Directors that accompanies official NBER publications.

(C) 2010 by Takatoshi Ito, Satoshi Koibuchi, Kiyotaka Sato, and Junko Shimizu. All rights reserved. Short sections of text, not to exceed two paragraphs, may be quoted without explicit permission provided that full credit, including $\odot$ notice, is given to the source. 
Why has the yen failed to become a dominant invoicing currency in Asia? A firm-level analysis of Japanese Exporters' invoicing behavior

Takatoshi Ito, Satoshi Koibuchi, Kiyotaka Sato, and Junko Shimizu

NBER Working Paper No. 16231

July 2010

JEL No. F23,F31,F33

\section{ABSTRACT}

It has been a well-known puzzle why the yen has not been used more in trade invoicing among Japanese exporters. Despite the yen's status as an only fully convertible currency in Asia, two patterns stand out as puzzling features of an excessively small share of yen invoicing: First, a strong tendency of Japanese exporters to choose importer's currency in their exports to advanced countries, and second, the prevalence of US dollar invoicing in Japanese exports to East Asia even though Japanese firms have built a regional production network in the last two decades. New possible determinants of currency invoicing at a firm-level are found through interviews with Japanese representative exporting firms. Invoicing behavior is examined by probit estimation using the unique data set on the firms' currency invoicing choice by destination. Our novel findings suggest that a surprisingly low share of yen invoicing among Japanese exports even in the 2000s can be attributable to (1) a scale-economy in concentrating currency risk at the headquarter as intra-firm trades with overseas operations of Japanese firms grew; and (2) the production/trade structure of Japanese electronics companies in Asia in which final products tend to be exported to the United States or Europe.

Takatoshi Ito

Graduate School of Economics

University of Tokyo

7-3-1 Hongo, Bunkyo-ku, Tokyo 113-0033

JDSDQ

and NBER

ITOINTOKYO@aol.com

Satoshi Koibuchi

Chuo University

Faculty of Commerce

742-1 Higashi Nakano

Hachioji, Tokyo, 192-0393 Japan

koibuchi@tamacc.chuo-u.ac.jp
Kiyotaka Sato

Yokohama National University

Faculty of Economics,

79-3 Tokiwadai, Hodogaya-ku

Yokohama, 240-8501, Kanagawa

Japan

sato@ynu.ac.jp

Junko Shimizu

Senshu University

School of Commerce

2-1-1, Higashi Mita

Kawasaki, 214-8580, Japan

jshimizu@isc.senshu-u.ac.jp 


\section{Introduction}

Exporter's price setting and currency invoicing practices have important implications for how macroeconomic shocks are transmitted to and from foreign countries. Whereas a lot of attention has been paid to this issue, detailed data and information on the invoicing choice by industry/commodity and by destination/source country are rarely published or disclosed. Although the aggregate data are available in some countries, they are not sufficient for a rigorous empirical examination.

There are three strands of empirical studies on the invoicing choice. The first strand of research is to conduct a cross-country analysis of the invoicing choice by collecting as many information as possible on the share of currency invoicing at a country level (Goldberg and Tille, 2008, Kamps, 2006). Second, Goldberg and Tille (2009) utilize the highly detailed Canadian import data at a customs level spanning from February 2002 to February 2009 with rich information on the source country, invoice currency, and value of transactions, etc. ${ }^{1}$ The determinants of invoicing currency choice in Canadian imports are empirically tested using a large number of observations. It is difficult to follow the approach of Goldberg and Tille (2009) because such a highly detailed customs level data is rarely available. Third, Friberg and Wilander (2008) made a questionnaire survey analysis with Swedish exporting firms and conducted empirical tests on determinants of currency invoicing, which is a useful approach to obtain the detailed data at a firm level.

The purpose of this paper is to analyze the determinants of currency invoicing in Japanese exports. To overcome the limitation of data availability, we employ a different approach from the previous studies. Specifically, we conducted interviews with 23 Japanese representative firms in the four industries - automobile, electrical machinery, general machinery and electrical component-in order to obtain information on their currency invoicing practices and their exchange rate risk management. New evidence on the destination breakdown share of currency invoicing is obtained for the above four industries. It is found that (1) Japanese exporters tend to invoice in importer's currency when destination is an advanced country and (2) the share of US dollar invoicing is larger than that of yen invoicing in Japanese exports to Asia. They violate one of the well-known stylized facts of the currency invoicing pattern, such as Grassman $(1973,1976)$. To solve these puzzles, we conducted interviews of (the finance department of) representative Japanese firms. The following possible determinants of currency invoicing among Japanese exporters emerged from the interviews: (i) Who are trading partners. Intra- or inter-firm trade, or exports through Sogo Shosha (Japanese trading companies); (ii) Costs of exchange rate hedging; (iii) The degree of market competition and differentiation of exporting products; (iv) Exports from Asian production base to the final retail

\footnotetext{
${ }^{1}$ Donnenfeld and Haug $(2003,2008)$ also use the similar data set in testing the determinants of currency invoicing in Canadian and US imports.
} 
destination, namely the US market. We supplement the survey with a firm-level data set obtained from annual financial statements of each sample firm, we conduct probit estimation to reveal the determinants of currency invoicing at a firm-level export.

Our novel findings are three-fold. First, invoicing in importer's currency is prevalent in Japanese exports to advanced countries, because most of their exports are destined for local retail subsidiaries. To the extent that the sales and/or production subsidiaries face severe competition in the local markets, Japanese parent firms have a strong tendency to assume an exchange rate risk of intra-firm trade by invoicing in the local (importer's) currency, which conforms to the pricing-to-market (PTM) behavior discussed in the literature. ${ }^{2}$ Second, Japanese firms that export highly differentiated products or have a dominant share in global markets tend to invoice their products in the yen for exports to advanced countries as well as exports to developing countries. Third, although Japanese firms have shifted their production bases to Asian countries, exports from these Asian production subsidiaries tend to be invoiced in US dollars as long as the final destination market is in the United States. Then in order to avoid currency risk at the assembly in Asia, Japanese parents export with invoices in the US dollar even in exports from Japanese head office to the production subsidiaries in Asia. Thus, a smaller share of yen invoicing in Japanese exports even in the 2000s is due not only to the growing intra-firm trade promoted by active overseas operations of Japanese firms but also to the development of Japanese production network and trade structure in Asia driven mainly by Japanese electronics companies. As long as US dollar invoicing is prevalent in Asia, both Japanese and Asian firms have no choice but to take exchange rate risks against the US dollar. This aspect will have important implications for a new strategy of optimal exchange rate risk management and, hence, establishing regional currency arrangements such as a common currency basket in East Asia.

The remainder of this paper is organized as follows. Section 2 discusses the puzzling evidences of the Japan's currency invoicing pattern. Section 3 explains the details of our interview analysis. In Section 4, the new evidence of the Japanese currency invoicing pattern at a firm level is presented. In Section 5, possible determinants of an invoice currency are derived from the interview analysis. These determinants are tested empirically using a new firm-level dataset. Finally, Section 6 concludes.

\section{Puzzles of the Japanese Currency Invoicing Pattern}

It is often pointed out that the currency invoicing pattern of Japanese trade differs markedly

\footnotetext{
${ }^{2}$ For an empirical analysis of the PTM behavior, see inter alia Knetter (1989, 1992), Marston (1990), Takagi and Yoshida (2001) and Parsons and Sato (2008).
} 
from that of other advanced countries. ${ }^{3}$ Table 1 compares the share of both domestic currency invoicing and US dollar invoicing across six advanced countries. First, the Japan's share of domestic currency invoicing is the smallest among the six countries even in the 2000s. Only 40.1 percent and 23.8 percent are invoiced in the yen as of 2004 in Japan's exports and imports, respectively. Second, the US dollar invoicing is particularly high in Japan's exports and imports compared to other advanced countries except the United States. It is only in Japan that the share of US dollar invoicing exceeds that of the domestic currency invoicing in both exports and imports.

Table 1. International Comparison of Currency Invoicing of Advanced Countries (\%)

\begin{tabular}{l|r|r|r|r|r|r|r|r|r}
\hline & \multicolumn{3}{c}{ (a) Home Currency Invoicing Ratio: Exports } & \multicolumn{2}{c}{ (b) US Dollar Invoicing Ratio: Exports } \\
\cline { 2 - 3 } \cline { 7 - 8 } & 1980 & 1988 & $1992-96$ & $2002-04$ & 1988 & 1988 & $1992-96$ & $2002-04$ \\
\hline United States & 97.0 & 96.0 & 98.0 & 95.0 & 97.0 & 96.0 & 98.0 & 95.0 \\
\hline Germany & 82.3 & 79.2 & 76.4 & 61.1 & 7.2 & 8.0 & 9.8 & 24.1 \\
\hline Japan & 28.9 & 34.3 & 35.9 & 40.1 & 66.3 & 53.2 & 53.1 & 47.5 \\
\hline United Kingdom & 76.0 & 57.0 & 62.0 & 51.0 & 17.0 & n.a. & 22.0 & 26.0 \\
\hline France & 62.5 & 58.5 & 51.7 & 52.7 & 13.2 & n.a. & 18.6 & 33.6 \\
\hline Italy & 36.0 & 38.0 & 40.0 & 59.7 & 30.0 & n.a. & 23.0 & n.a. \\
\hline
\end{tabular}

(c) Home Currency Invoicing Ratio: Imports

\begin{tabular}{|c|c|c|c|c|c|c|c|c|}
\hline & \multicolumn{4}{|c|}{ 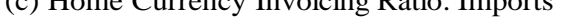 } & \multicolumn{4}{|c|}{ 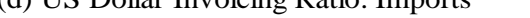 } \\
\hline & 1980 & 1988 & $1992-96$ & 2002-04 & 1980 & 1988 & $1992-96$ & 2002-04 \\
\hline United States & 85.0 & 85.0 & 88.8 & 85.0 & 85.0 & 85.0 & 88.8 & 85.0 \\
\hline Germany & 43.0 & 52.6 & 53.3 & 52.8 & 32.3 & 21.3 & 18.1 & 35.9 \\
\hline Japan & 2.4 & 13.3 & 20.5 & 23.8 & 93.1 & 78.5 & 72.2 & 69.5 \\
\hline United Kingdom & 38.0 & 40.0 & 51.7 & 33.0 & 29.0 & n.a. & 22.0 & 37.0 \\
\hline France & 34.1 & 48.9 & 48.4 & 45.3 & 33.1 & n.a. & 23.1 & 46.9 \\
\hline Italy & 18.0 & 27.0 & 37.0 & 44.5 & 45.0 & n.a. & 28.0 & n.a. \\
\hline
\end{tabular}

Notes: The 1992-96 data denotes March 1996 for the United States, 1994 for Germany, March 1996 for Japan, 1992 for the United Kingdom, 1995 for France, and 1994 for Italy. The 2002-04 data denotes 2003 for the United States, 2004 for Germany, the 2nd half of 2004 for Japan, 2002 for the United Kingdom, 2003 for France, and 2004 for Italy. For Germany, France and Italy, the 2002-04 data shows the share of euro invoicing.

Source: Deutsche Bundesbank (1991); Tavlas and Ozeki (1992); Tavlas (1997); Goldberg and Tille (2008); Kamps (2006); Bank of Japan, Yushutsu Shinyojo Tokei (Export Letter of Credit Statistics); MITI, Yunyu Shonin Todokede Hokokusho (Import Approval Notification Report); MITI, Yushutsu Kakunin Tokei (Export Confirmation Statistics); MITI, Yunyu Hokoku Tokei (Import Report Statistics); MITI, Yushutsu Kessai Tsukadate Doko Chosa (Export Settlement Currency Invoicing); MITI, Yunyu Kessai Tsukadate Doko Chosa (Import Settlement Currency Invoicing).

More generally, how is Japanese pattern of invoicing understood in light of the empirical regularities, or "classical stylized facts", discussed in the literature? The following stylized facts tell us that the invoicing choice is conditional on a trading partner country and the characteristics of goods

\footnotetext{
${ }^{3}$ See, for instance, Tavlas and Ozeki (1992), Ito (1993), Fukuda and Ji (1994), Kawai (1996) and Sato (1999).
} 
traded. ${ }^{4}$

Classical Stylized Fact 1: Trade of manufactured products between advanced countries tends to be invoiced in the exporter's currency, which is known as the "Grassman's Law" (Grassman, 1973, 1976).

Classical Stylized Fact 2: Trade of manufactured products between advanced and developing countries tends to be invoiced in the advanced country's currency or, to a lesser extent, in a major international currency such as the US dollar (Grassman, 1973, and Page, 1977, 1981).

Classical Stylized Fact 3: Differentiated products such as machinery products tend to be invoiced in the exporter's currency. More homogeneous products such as crude oil and primary commodity are typically invoiced in the international currency such as the US dollar (McKinnon, 1979).

Dose the Japan's currency invoicing pattern correspond to the classical stylized facts? Figure 1 shows that the Japanese currency invoicing pattern differs across destination countries (regions). First, in Japanese exports to the world, the share of the yen rose from 28.9 percent in 1980 to 42 percent in 1983, and then declined to 33.4 percent in 1987. Such a fall of the yen invoicing share from 1983 is generally attributed to the PTM strategy of Japanese exporters. ${ }^{5}$ Specifically, during a rapid appreciation period of the yen against the US dollar from 1985 to 1987, Japanese firms are said to have stabilized the selling price in the local (US) market by invoicing in US dollars in order to maintain their own market share. Since the mid-1980s to the present, the share of yen invoicing has fluctuated within the range from 30 to 40 percent in Japan's exports to the world.

Second, the destination breakdown data gives us more interesting evidence, though the data is available only from 1987. The share of yen invoicing is very low in exports to the United States, which may partly reflect a special position of the US dollar as an international currency (Tavlas and Ozeki, 1992). Even in exports to the Euro area, the share of yen invoicing has declined from 44.0 percent in 1987 to 28 percent in 2009. Although not reported in Figure 1(c), 50-51 percent of Japanese exports to EU were invoiced in the euro as of 2009. ${ }^{6}$ The above observation strongly suggests that Japanese firms tend to choose local currency invoicing in exports to advanced countries, which conflicts with the classical stylized fact 1 . This is one of the puzzles of the Japan's invoicing choice. As will be discussed below, this puzzle has to do with a growing intra-firm trade as well as the PTM behavior of Japanese exporting firms. ${ }^{7}$

\footnotetext{
${ }^{4}$ Ligthart and da Silva (2007) make a good literature review and propose the following three stylized facts.

${ }^{5}$ See Krugman (1987), Marston $(1990,1991)$ and Tavlas and Ozeki (1992).

${ }^{6}$ If including the UK pound in the local currency, the share of local currency invoicing in Japanese exports to EU amounts to 54-56 percent in 2009.

${ }^{7}$ For an empirical analysis of the PTM behavior and the exchange rate pass-through in Japanese exports, see
} 
Figure 1. Currency Invoicing of Japanese Exports: Yen and the US Dollar (\%)
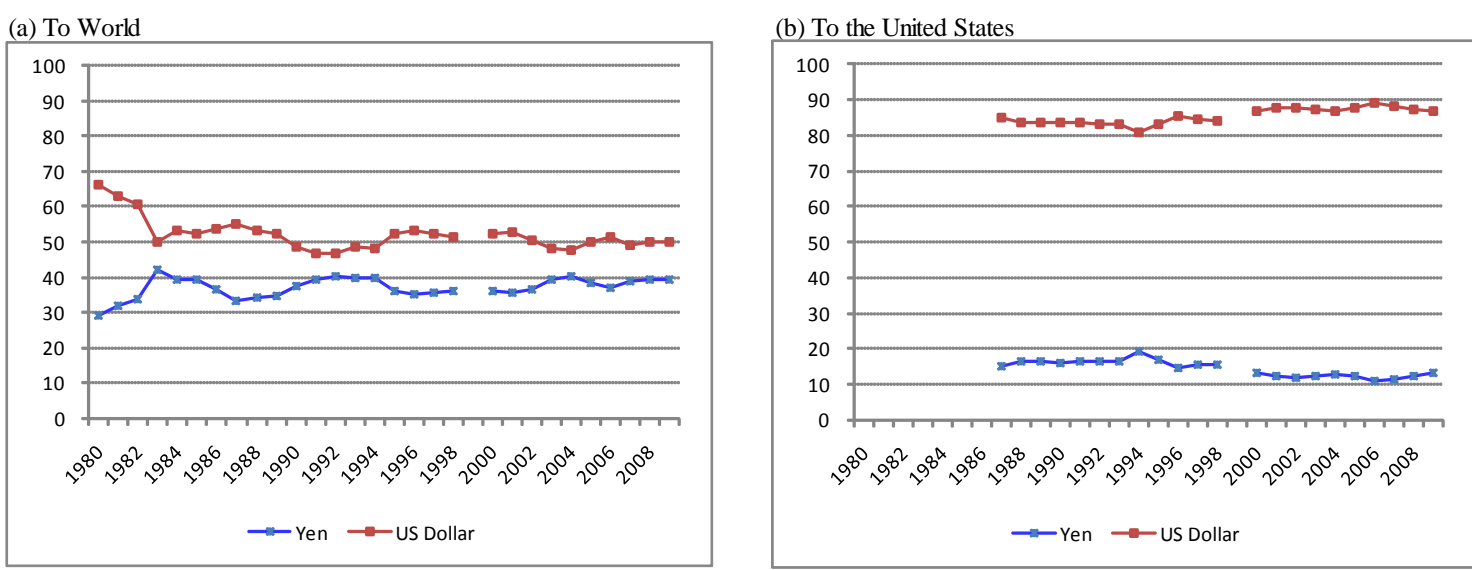

(c) To EU (EC)
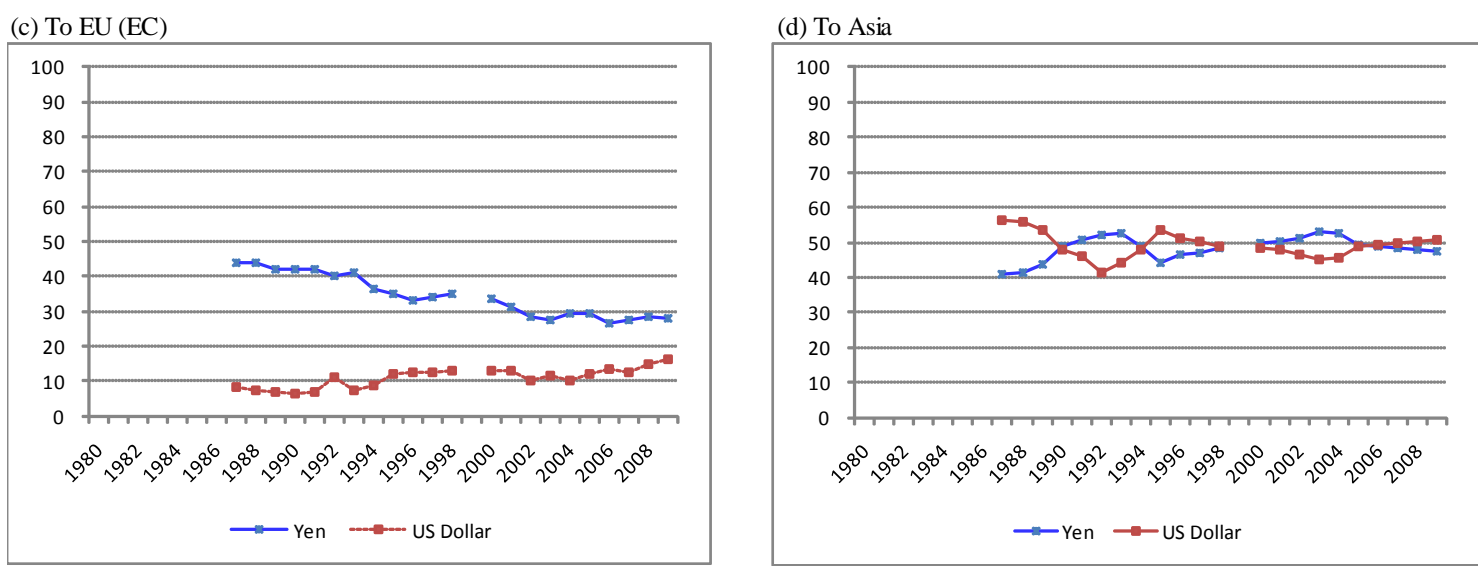

Notes: The data for 1999 is not available. The September data is used for 1992-97, the March data for 1998, and the 2nd half of the year data for 2000-09.

Source: Bank of Japan, Yushutsu Shinyojo Tokei (Export Letter of Credit Statistics); MITI, Yushutsu Kakunin Tokei (Export Confirmation Statistics); MITI, Yushutsu Hokukosho Tukadate Doko (Export Currency Invoicing Report); MITI, Yushutsu Kessai Tsukadate Doko Chosa (Export Settlement Currency Invoicing); the website of Japan Customs.

Third and more importantly, the share of yen invoicing has not increased much since 1990 in Japanese exports to Asia. Specifically, the share of both the yen and the US dollar accounts for about 50 percent from the 1990s to 2009 in Japanese exports to Asia, and the share of US dollar invoicing exceeds that of yen invoicing for the last few years (Figure 1(d)). This evidence is contradictory to the classical stylized fact 2, in that the share of US dollar invoicing accounts for 50 percent or more in Japan's total exports to Asia.

Such an invoicing pattern is puzzling, because until around the mid-1990s, when a question of the internationalization of the yen was lively debated, it was generally conjectured that the use of Knetter (1989, 1992), Marston (1990), Takagi and Yoshida (2001) and Parsons and Sato (2008). 
the yen as an invoice currency would be growing in Asia if intra-firm trade increased between Japanese parent companies and local subsidiaries through active foreign direct investment in Asia by Japanese firms. ${ }^{8}$ In particular, as most exports from Japan to Asia were regarded as capital goods and differentiated products, the share of yen invoicing was expected to increase steadily, as suggested by the classical stylized fact 3. Figure 1(d) clearly shows, however, that the share of yen invoicing has not increased from 1990 to the present, even though Japanese firms have built a regional production network during that period. Instead, US dollar invoicing is far more prevalent than suggested by the classical stylized facts. To get a clue to understanding of this second puzzle of the Japan's currency invoicing pattern, it is necessary to obtain the detailed data on the invoicing choice of Japanese exports both by commodity/industry and by destination. Since the detailed data is not published, we conducted an interview analysis with major Japanese exporting firms to collect a firm-level data, which will be discussed in the next section.

\section{The Interview with Major Japanese Exporting Firms}

\section{3-1. Sample Firms of the Interview Analysis}

To solve the puzzles of Japan's currency invoicing pattern, we conducted an interview with 23 Japanese representative exporting companies in two consecutive years: the 1st interview was in 2007 (September-November 2007) and the 2nd interview in 2008 (July-December 2008). ${ }^{9}$ The 23 sample firms were chosen from four major machinery industries: the automobile, electrical machinery, machinery, and electrical component industries. ${ }^{10}$

Our strategy of an interview analysis is to focus on the two largest industries, the electrical machinery and automobile industries, in terms of export amounts and sales abroad. Table 2 shows the basic information of our sample firms. We finally made an interview with 9 firms in the automobile industry and with 7 firms in the electrical machinery industry. In terms of foreign sales, the 9 automobile firms account for 79 percent of all transport equipment firms that are listed in Tokyo Stock Exchange (TSE) in the fiscal year 2007. The share of our 7 electrical machinery firms also amounts to 55 percent of all electric appliance firms listed in TSE. Thus, although the share is very small in terms

\footnotetext{
${ }^{8}$ Kawai (1996), for instance, pointed out that the international use of the yen would naturally grow as Japan's economic interdependence with Asia deepened through intra-industry trade, foreign direct investments and various types of financial flows.

${ }^{9}$ In most cases, we made an interview with a director of the finance department of sample firms based on the questionnaires that we had sent before visiting them.

${ }^{10}$ As might be expected, it is very difficult to make an appointment with Japanese companies for interview. With the help of METI and RIETI, we could finally interview 23 machinery companies. Due to the time constraint, we could not interview with many candidate companies from the machinery and electrical component industries.
} 
of the number of firms, the result of interviews with our sample firms provides a comprehensive picture of currency invoicing practices of major Japanese exporting firms.

Table 2. Basic Information on the Sample Firms: Foreign Sales in FY2007

\begin{tabular}{|c|c|c|c|c|c|}
\hline TSE industry classification & $\begin{array}{l}\text { Transportation } \\
\text { Equipments }\end{array}$ & \multicolumn{2}{|c|}{ Electric Appliance } & Machinery & $\begin{array}{c}\text { Total } 3 \\
\text { industries }\end{array}$ \\
\hline $\begin{array}{l}\text { Number of listed firms with foreign } \\
\text { sales }(>=10 \%) \text { in FY2007 }\end{array}$ & 83 & \multicolumn{2}{|c|}{221} & 168 & 472 \\
\hline $\begin{array}{l}\text { Foreign sales in FY2007 } \\
\text { (Sum total, billion yen) }\end{array}$ & 61,958 & \multicolumn{2}{|c|}{48,366} & 11,455 & 121,781 \\
\hline $\begin{array}{l}\text { Foreign sales / Consolidated sales } \\
\text { (sample average, \%) }\end{array}$ & $46 \%$ & \multicolumn{2}{|c|}{$44 \%$} & $43 \%$ & --- \\
\hline Sample firms by industry & Automobile & $\begin{array}{l}\text { Electrical } \\
\text { Machinery }\end{array}$ & $\begin{array}{l}\text { Electrical } \\
\text { Components }\end{array}$ & Machinery & $\begin{array}{l}\text { Total sample } \\
\text { firms }\end{array}$ \\
\hline $\begin{array}{l}\text { Number of sample firms } \\
\text { [Percent to all listed firms] }\end{array}$ & $\begin{array}{c}9 \\
{[11 \%]}\end{array}$ & $\begin{array}{c}7 \\
{[3 \%]}\end{array}$ & $\begin{array}{c}4 \\
{[2 \%]}\end{array}$ & $\begin{array}{c}3 \\
{[2 \%]}\end{array}$ & $\begin{array}{c}23 \\
{[5 \%]}\end{array}$ \\
\hline $\begin{array}{l}\text { Foreign sales in FY2007 } \\
\text { (Sum total, billion yen) } \\
\text { [Percent to all listed firms] }\end{array}$ & $\begin{array}{r}48,756 \\
{[79 \%]}\end{array}$ & $\begin{array}{r}26,379 \\
{[55 \%]}\end{array}$ & $\begin{array}{r}1,992 \\
{[4 \%]}\end{array}$ & $\begin{array}{l}2,115 \\
{[18 \%]}\end{array}$ & $\begin{array}{r}79,243 \\
{[65 \%]}\end{array}$ \\
\hline $\begin{array}{l}\text { Foreign sales / Consolidated sales } \\
\text { (sample average, \%) }\end{array}$ & $67 \%$ & $52 \%$ & $68 \%$ & $70 \%$ & --- \\
\hline
\end{tabular}

1) In the Tokyo Stock Exchange (TSE)'s industry classification, "Transportation Equipments (Yuso-yo kiki)" includes companies related to automobiles, motorcycles, and shipbuilding, while "Electric Appliances (Denki Kiki)" mainly includes electrical machinery and electrical components.

2) In the Japanese accounting standard, all listed firms have to report the amount of foreign sales in their financial statement as long as their ratio of "foreign sales-to-consolidated sales" is 10 percent or more.

Source: Financial statements of all listed companies with "Foreign Sales (Kaigai Uriage-daka)" in FY2007.

In addition, we made an additional interview with 4 electrical component firms and with 3 machinery firms. Some of these firms are said to have strong competitiveness in their exports, as they have a large market share or export highly differentiated products, which enables us to take into account in our analysis the currency invoicing practices of these companies that have strong export competitiveness. Other firms, especially electrical component firms, operate actively in Asian by building a production network and facilitating intra-firm trade. These aspects will give us new insights into the puzzles of Japanese exporter's invoicing practices.

\section{3-2. Questionnaires}

Our interview research is conducted based on the questionnaire entries that are composed of the following four topics. 
(1) Production and Sales Structure: To comprehend the profile of each company, we asked the following questions: (i) the production structure (whether to have overseas production subsidiaries), (ii) the sales structure (whether to have overseas sales subsidiaries and regional head quarters; whether to trade through Sogo Shosha (Japanese trading companies); whether there is any difference between physical distribution and commercial distribution of goods), (iii) characteristics of goods traded (such as competitiveness and market share), (iv) Basic policy on the exchange rate risk management.

(2) Invoice Currency: Our main interest is in collecting the destination breakdown data on currency invoicing at a firm level. Our questions are which currency is used (i) in exports from Japan to each destination country, (ii) in exports from Japan to overseas sales and/or production subsidiaries, and (iii) in exports from overseas production subsidiaries to final destination markets. Furthermore, we asked whether the invoicing choice is affected by (iv) inter- or intra-firm trade and by (v) characteristics of products traded such as the degree of product differentiation.

(3) Exchange Rate Risk Management: We asked questions about which kind of hedging strategies they use (forward, future and options through market, marry and netting, etc.)

(4) Revision of Price Setting: Our question is whether they periodically change the export price itself irrespective of the invoicing choice. We also asked whether they have any explicit policy of price revision in the face of sharp and large fluctuations of the exchange rate.

\section{New Evidence of the Choice of an Invoice Currency}

Through the interviews, we obtained the detailed data on currency invoicing from most sample firms. To assure anonymity, however, the actual share of currency invoicing for each sample firm will not be presented in this paper. Instead, we present the evidence of the sample firms' invoicing choice in the following two ways.

\section{4-1. The Share of Currency Invoicing by Industry}

We first aggregate the firm-level data into the industry share of currency invoicing in exports to the world and Asia. Sample mean and median (in parenthesis) of the invoicing share for each industry are reported in Table 3. Not all sample firms answered the share of currency invoicing in 
exports to the world and Asia: 14 out of 23 firms answered the invoicing share in exports to the world and 18 out of 23 firms in exports to Asia. For the rest of sample firms, we reasonably assess the share of currency invoicing for each firm. Suppose some firms did not show us the invoicing share in exports to the world, but provided us with the information on the invoicing share in exports to North America (the United States), the Euro area and Asia. In this case, we obtained the regional breakdown data on their foreign sales from the annual securities report of the sample firms concerned, which enables us to compute the firm's invoicing share in exports to the world with the reasonable assumption that the firm's exports are destined for the above three regions. ${ }^{11}$ As a result, the data for 21 firms are used to calculate the simple average share of currency invoicing in exports to the world, and the data for 22 firms in exports to Asia.

The following notable pattern of currency invoicing is observed in Table 3. First, when looking at the simple average share (all sample firms) of currency invoicing in exports to the world, the US dollar accounts for 51.6 percent, the euro 14.0 percent, and the yen 29.9 percent. The share of US dollar invoicing is somewhat higher in Table 3 than in Figure 1, while the yen invoicing share is lower in Table 3 than in Figure 1. It is true even in the simple average share in exports to Asia. This observation suggests that our sample firms have a tendency to use the US dollar more (the yen less) than what we observed in Figure 1.

Second, turning to the industry data, there is a marked difference in the invoicing pattern across industries. In exports to the world, more than 70 percent are invoiced in US dollars in the electrical machinery and electrical component industries, while only about 12 percent are in the yen. In contrast, the share of yen invoicing is 61.7 percent in exports of machinery firms to the world, which may reflect machinery firms' relative strength in export competitiveness.

Third, turning to exports to Asia, the difference in the invoicing choice across industries becomes far more evident. The share of US dollar invoicing is 93 percent in the electrical machinery industry and 88.8 percent in the electrical component industry, while the share of yen invoicing is 80 percent in the machinery industry. More interestingly, the share of yen invoicing in exports to Asia becomes much higher (65.6 percent) in the automobile industry. To solve the puzzles, that is the high share of dollar in exports to Asia, of Japan's currency invoicing pattern, it is necessary to analyze why such a sharp difference is observed across industries and how the industry characteristics are related with the invoicing choice.

\footnotetext{
${ }^{11}$ Because of a lack of information, we could not assess the invoicing share reasonably for two electrical machinery firms, whose data were treated as a missing value.
} 
Table 3. Industry Breakdown of the Currency Invoicing Share: Interview Results (\%)

\begin{tabular}{|c|c|c|c|c|c|c|c|c|c|}
\hline \multirow{2}{*}{ Sample firms } & \multicolumn{3}{|c|}{$\begin{array}{l}\text { Share of currency for exports } \\
\text { from Japan to the world }{ }^{2)}\end{array}$} & \multicolumn{2}{|c|}{$\begin{array}{l}\text { Share of currency for } \\
\text { exports } \\
\text { from Japan to Asia }\end{array}$} & \multirow{2}{*}{$\begin{array}{l}\text { Share of } \\
\text { foreign } \\
\text { sales in } \\
\text { total sales }\end{array}$} & \multicolumn{3}{|c|}{ Share of foreign sales by region ${ }^{4)}$} \\
\hline & USD & EUR & JPY & USD & JPY & & $\begin{array}{l}\text { North } \\
\text { America }\end{array}$ & Europe & Asia \\
\hline \multirow{2}{*}{ All sample firms } & 51.6 & 14.0 & 29.9 & 55.6 & 41.8 & 61.8 & 27.6 & 25.5 & 39.1 \\
\hline & $(50.6)$ & $(15.0)$ & $(25.0)$ & $(57.5)$ & $(32.2)$ & $(68.1)$ & (28.3) & $(25.9)$ & $(37.5)$ \\
\hline Automobile & 40.0 & 15.3 & 36.9 & 32.6 & 65.6 & 64.8 & 31.1 & 23.3 & 31.1 \\
\hline Electrical machinery & 70.9 & 15.3 & 12.6 & 93.0 & 6.4 & 52.6 & 32.5 & 34.9 & 32.5 \\
\hline Machinery & 28.3 & 10.0 & 61.7 & 20.0 & 80.0 & 69.8 & 22.0 & 22.7 & 48.2 \\
\hline $\begin{array}{l}\text { Electrical } \\
\text { components }\end{array}$ & 71.1 & 12.5 & 12.2 & 88.8 & 9.4 & 67.8 & 19.1 & 20.8 & 57.0 \\
\hline
\end{tabular}

1) Sample average and sample mean (in parentheses) are reported.

2) "Share of currency for exports from Japan to the world" reports the sample average share of 21 firms excluding two electrical machinery firms that did not give us any data on the share of currency invoicing. "Share of currency for exports from Japan to Asia" presents the sample average share of 22 firms excluding one electrical machinery firm.

3) "Share of foreign sales to total sales" is calculated as the share of foreign sales in each region in the total foreign sales. The data is collected from the consolidated financial statement report of the latest accounting term corresponding to the interview research period (the fiscal year end of 2006 or 2007).

Source: Interview with 23 major Japanese exporters and their financial statements

Fourth, Table 3 does not show any clear relationship between the invoicing share and the share of foreign sales by region. The sixth through ninth columns in Table 3 report the average share of foreign sales and the regional breakdown of the share of foreign sales. ${ }^{12}$ Interestingly, the share of sales in Asia differs markedly across industries. The machinery and electrical component industries show a very high share of sales in Asia: 48.2 percent in the machinery industry and 57 percent in the electrical component industry. However, these two industries show a very different pattern of the invoicing choice as discussed above.

\section{4-2. The "Main Invoice Currency" by Region}

We have so far investigated the currency invoicing choice of major Japanese firms by industry. To advance our analysis of the destination specific invoicing choice while assuring anonymity of the sample firms, we employ the "main invoice currency" approach in this subsection.

\footnotetext{
12 "Foreign sales by region" reported in the consolidated financial statement of the annual securities report is not identical to the export from Japan to each region, because the former includes the data on the sales of overseas subsidiaries in the local market and/or abroad. Nevertheless, "foreign sales by region" can be regarded as a proxy variable for the share of exports from Japan to each region. For further details, see Appendices 4 and 5.
} 
The main invoice currency is defined as the most frequently used currency in exports to the destination country. Our interview analysis reveals that a single currency tends to be used in exports to each destination. However, there are several firms that use two or more invoice currencies in exports to a single destination country, in which case the main invoice currency does not mean that the currency is 100 percent used in exports. ${ }^{13}$

Table 4 shows the currency invoicing in exports from Japan to advanced countries including Mexico and Russia. In this table, we count the number of firms that use one of four currencies as the main invoice currency for each destination. For instance, looking at the far left of the first row in Table 4, [20/22] indicates that 20 out of 22 sample firms use the US dollar as the main invoice currency in exports to the United States. Industry breakdown data are also reported in the 2nd through 5th rows. No figures in the table mean that the firm does not export to the region/country in question, or that we could not get any clear answers about the main invoice currency.

Table 4 shows the choice of the main invoice currency by destination and by industry in 2007-2008. First, importer's currency invoicing is prevalent in Japanese exports to advanced countries. In exports to the United States, 20 out of 22 firms use the US dollar as the main invoice currency. In exports to the Euro area, 14 out of 21 firms choose the euro as the main invoice currency, while the yen is the main invoice currency for 5 firms. The importer's currency is evidently chosen even in exports to UK, Australia and Canada.

Second, in contrast to the case of advanced countries, the importer's currency is rarely used in Mexico and Russia. Instead, the US dollar is chosen as the main invoice currency in both countries. Third, even in exports to the United States and the Euro area, several Japanese firms in machinery and electrical component industries use the yen as the main invoice currency. These firms clearly answered to our interviews with recognition of high export competitiveness in the global markets. This conforms with stylized fact No. 3. Fourth, the electrical machinery firms do not use the yen at all as the main invoice currency. Interestingly, US dollar invoicing is chosen even in Japanese exports to some advanced countries other than the United States.

The above observation indicates the strong tendency of major Japanese exporting firms to use the importer's currencies as the main invoice currency in exports to advanced countries, which conforms to the PTM behavior discussed earlier. From a standpoint of the foreign exchange risk management, the importer's currency invoicing means that the foreign exchange risks are taken and managed by the headquarter of Japanese exporting firms.

\footnotetext{
${ }^{13}$ For example, we regard the US dollar as the main invoice currency in exports to Asia, if 50 percent of its exports to Asia are invoiced in US dollars, 30 percent in the local currency, and 20 percent in the yen. Friberg and Wilander (2008) also employ this main invoice currency approach for their questionnaire survey analysis and conduct empirical examination.
} 
Table 4. Currency invoicing in exports from Japan to North America, Europe and Australia

\begin{tabular}{|c|c|c|c|c|c|c|c|c|}
\hline \multirow{2}{*}{\multicolumn{2}{|c|}{$\begin{array}{l}\text { Main invoice } \\
\text { currency for } \\
\text { exports }\end{array}$}} & \multicolumn{7}{|c|}{ Destination country or region } \\
\hline & & US & Canada & Mexico & Euro area & UK & Russia & Australia \\
\hline \multirow[t]{5}{*}{ USD } & & {$[20 / 22]$} & {$[2 / 10]$} & {$[4 / 5]$} & {$[2 / 21]$} & {$[1 / 8]$} & {$[2 / 3]$} & \\
\hline & Automobile & 8 & 1 & 2 & & & 2 & \\
\hline & Electrical machinery & 7 & 1 & & 2 & 1 & & \\
\hline & Machinery & 2 & & 1 & & & & \\
\hline & Electrical components & 3 & & 1 & & & & \\
\hline \multirow[t]{5}{*}{ Euro } & & & & & {$[14 / 21]$} & {$[1 / 8]$} & & \\
\hline & Automobile & & & & 6 & & & \\
\hline & Electrical machinery & & & & 5 & & & \\
\hline & Machinery & & & & 1 & 1 & & \\
\hline & Electrical components & & & & 2 & & & \\
\hline \multicolumn{2}{|c|}{ Importer's currency } & --- & {$[8 / 10]$} & {$[1 / 5]$} & $\begin{array}{l}-- \\
-\end{array}$ & {$[6 / 8]$} & {$[1 / 3]$} & {$[7 / 7]$} \\
\hline & Automobile & -- & 4 & 1 & --- & 4 & & 4 \\
\hline & Electrical machinery & --- & 3 & & --- & 2 & & 3 \\
\hline & Machinery & --- & 1 & & --- & & 1 & \\
\hline & Electrical components & --- & & & -- & & & \\
\hline \multirow[t]{5}{*}{$\overline{J P Y}$} & & {$[2 / 22]$} & & & {$[5 / 21]$} & & & \\
\hline & Automobile & & & & 1 & & & \\
\hline & Electrical machinery & & & & & & & \\
\hline & Machinery & 1 & & & 2 & & & \\
\hline & Electrical components & 1 & & & 2 & & & \\
\hline
\end{tabular}

Note: This table counts the number of firms that use one of four currencies as the main invoice currency for each destination. For instance, looking at the far left of the first row in this table, [20/22] indicates that 20 out of 22 sample firms use the US dollar as the main invoice currency in exports to the United States.

Source: Interview analysis with 23 major Japanese exporting firms.

Let us next turn to the choice of the main invoice currency in Japanese exports to Asia (Table 5). First and the most distinctive feature is that, in exports to Asia as a whole, the importer's currency is not used as the main invoice currency. The importer's currency invoicing is observed only in exports to a particular destination country. Interestingly, the Chinese yuan is not used at all as the main invoice currency in exports to China that is the largest market in the region. This part is not surprising because Japan is an advanced country and most Asian countries are still developing countries. Second, sample firms dominantly use either the US dollar or the yen as the main invoice currency: 13 out of 22 firms choose the US dollar, while 9 firms use the yen. The extensive use of the US dollar is somewhat surprising since it is a third country currency. This part needs more examinations. Third, the choice of an invoice currency varies across industries. Firms in both the electrical machinery and the electrical component industries tend to use the US dollar, while the automobile firms tend to choose the yen. More interestingly, the yen tends to be used more in automobile and, especially, machinery exports to Asia, which contrasts markedly with the electrical machinery and electrical component firms. 
Table 5. Currency invoicing in exports from Japan to Asia

\begin{tabular}{|c|c|c|c|c|c|c|c|c|c|c|c|}
\hline \multirow{2}{*}{$\begin{array}{l}\text { Main } \\
\text { invoice } \\
\text { currency } \\
\text { for exports }\end{array}$} & & \multicolumn{10}{|c|}{ Destination country or region } \\
\hline & & Asia $^{1)}$ & China & Thai & $\begin{array}{c}\text { Indones } \\
\text { ia }\end{array}$ & \multirow{2}{*}{$\begin{array}{c}\begin{array}{c}\text { Singapo } \\
\text { re }\end{array} \\
{[6 / 7]} \\
\end{array}$} & \multirow{2}{*}{$\begin{array}{c}\begin{array}{c}\text { Malaysi } \\
\text { a }\end{array} \\
{[1 / 4]} \\
\end{array}$} & \multirow{2}{*}{$\begin{array}{r}\text { Korea } \\
{[2 / 4]}\end{array}$} & \multirow[t]{2}{*}{$\begin{array}{l}\text { Hong } \\
\text { Kong }\end{array}$} & \multirow{2}{*}{$\begin{array}{c}\text { Taiwan } \\
{[2 / 2]}\end{array}$} & India \\
\hline \multirow[t]{5}{*}{ USD } & & {$[13 / 22]$} & [6/11] & {$[1 / 6]$} & {$[2 / 5]$} & & & & & & \\
\hline & Automobile & 3 & & 1 & 1 & & & & & & \\
\hline & Electrical machinery & 7 & 3 & & & 2 & 1 & 1 & & & \\
\hline & Machinery & & & & 1 & 1 & & & & 1 & \\
\hline & Electrical components & 3 & 3 & & & 3 & & 1 & & 1 & \\
\hline \multicolumn{2}{|c|}{ Importer's currency } & & & {$[2 / 6]$} & {$[1 / 5]$} & {$[1 / 7]$} & {$[2 / 4]$} & {$[1 / 4]$} & {$[1 / 2]$} & & \\
\hline & Automobile & & & 1 & 1 & & & 1 & 1 & & \\
\hline & Electrical machinery & & & 1 & & 1 & 1 & & & & \\
\hline & Machinery & & & & & & & & & & \\
\hline & Electrical components & & & & & & 1 & & & & \\
\hline \multirow[t]{5}{*}{ JPY } & & {$[9 / 22]$} & [5/11] & {$[3 / 6]$} & {$[2 / 5]$} & & {$[1 / 4]$} & {$[1 / 4]$} & {$[1 / 2]$} & & {$[2 / 2]$} \\
\hline & Automobile & 5 & 3 & 2 & 2 & & 1 & & 1 & & 1 \\
\hline & Electrical machinery & & & & & & & & & & \\
\hline & Machinery & 3 & 2 & 1 & & & & 1 & & & 1 \\
\hline & Electrical components & 1 & & & & & & & & & \\
\hline
\end{tabular}

1) "Asia" includes China, three Asian NIEs (Korea, Taiwan and Hong Kong), and ASEAN countries. It also includes India if the sample firms export their goods from Japan to India.

Source: Interview analysis with 23 major Japanese exporting firms.

\section{Empirics of Invoicing Decision}

\section{5-1. Determinants of Currency Invoicing in Japanese Exporting Firms}

Through a face-to-face discussion with each firm, we obtained the following possible determinants of currency invoicing. The details are concisely summarized in Appendix 3.

\section{(i) To Whom to Sell: Intra-firm, outside firm or trading companies (Sogo Shosha)}

Almost all sample firms clearly state that a majority of their exports to advanced countries are destined for their own local subsidiaries (i.e., intra-firm trade). To free their local subsidiaries from any exchange rate risks, the Japanese headquarters have a strong tendency to choose invoicing in importer's currency and to manage all exchange rate risks at the finance department of its head office. In contrast, a substantial portion of exports to Asia and other developing countries are directed toward independent firms or joint ventures with a low share of ownership, in which case Japanese headquarters have less incentive to take the exchange rate risk. In these cases, there is a tendency to 
invoice not in the importer's currency but in the yen for exports to Asia and other developing countries. The ownership relationship with importers is different between advanced countries and developing countries, which tends to affect the choice of an invoice currency. We propose the following hypothesis that has not yet been formally stated or tested in the literature.

Hypothesis 1: The higher (lower) the ownership ratio or the equity participation is, the more (less) likely are Japanese firms to choose the importer's currency invoicing.

In addition, Japanese general trading companies, Sogo Shosha, play a certain role in the exporter's invoicing choice. In exports to developing economies, Japanese firms do not necessarily build their own distribution network. An alternative for exporters is to use Sogo Shosha that has developed its own global distribution channels/network especially in the market of developing countries. In the interviews, Japanese firms answered that their exports through Sogo Shosha were invoiced in the yen. Presumably, Sogo Shosha can manage currency risk very well, by marry, netting, and other ways. Thus, the share of yen invoicing will be growing if Japanese firms export more through Sogo Shosha. This hypothetical relationship has not been tested in the literature. ${ }^{14}$

Hypothesis 2: Japanese firms tend to invoice their export products in the yen when they export through Sogo Shosha.

\section{(ii) Cost of exchange rate hedging}

Many sample firms point out that the hedging cost of currency is one of the most important factors in choosing an invoice currency. The hedging cost of local currencies in Asia and other developing countries tends to be higher than that in advanced countries mainly due to various regulations and restrictions. Japanese exporting firms will not choose the importer's currency invoicing to the extent that the hedging cost is high between the yen and the importer's currency. ${ }^{15}$ Thus, the following hypothesis is typically tested in the empirical analysis of the invoicing choice.

Hypothesis 3: The higher (lower) the hedging cost between the yen and the importer's currency is, the lower (higher) is the use of the importer's currency as an invoice currency.

Although spot markets with underlying international transaction and investment are fully permitted in most Asian countries, onshore and offshore markets are mostly divided, which makes Asian forward

\footnotetext{
${ }^{14}$ When the internationalization of the yen was debated in the 1980s and the early 1990s, most studies pointed out that trade through Sogo Shosha had prevented yen-invoiced trade, since Sogo Shosha tends to use the US dollar in external trade, especially in importing crude oil and other natural resources (see, for instance, Kawai, 1996 and Fukuda and Ji, 1994). Our interview analysis, however, reveals the counter-evidence that exports through Sogo Shosha tend to be invoiced in the yen.

${ }^{15}$ Another possible determinant is the transaction cost of the currency. The US dollar is generally considered as a currency with the lowest transaction cost. It is widely recognized that the dominant use of the US dollar as a vehicle currency in foreign exchange markets is likely to facilitate the use of the US dollar as an invoice currency, even in trade between countries other than the United States. See Krugman $(1980,1984)$ for such a discussion.
} 
markets still undeveloped. The high transaction costs or the inconvenient risk hedge instruments have discouraged Japanese exporting firms to use Asian local currencies as invoice or settlement currencies.

\section{(iii) The degree of market competition and differentiation of exporting products}

As discussed above, the importer's currency invoicing prevails in exports to advanced countries, which has to do with the PTM behavior of Japanese firms. Specifically, many Japanese firms, especially those in automobile makers and electrical machinery industry, pointed out that it was too difficult to impose the exchange rate risk on importers in advanced countries due to high degree of competition in the markets. In contrast, a firm that exports differentiated products and has the largest market share in developing countries answered that its local subsidiaries could manage the exchange rate risk even when the headquarter chose yen-invoicing in exports to the local subsidiaries. Thus, the degree of product differentiation and market competition is an important factor in determining an invoice currency.

The result of our interview analysis conforms to both stylized fact no. 3 explained in earlier section and the recent theoretical development of the choice of an invoice currency. The previous studies, such as Giovannini (1988) and Donnenfeld and Zilcha (1991), model the firm's choice of an invoice currency by solving the maximization problem of the firm's expected profit with an uncertainty of exchange rate movements. They show that the choice of an invoice currency depends on the shape of the firm's profit function that is, in turn, conditional on the curvature of the demand function in the destination markets. The more (less) differentiated the firm's export product is, the lower (higher) the elasticity of demand for them is, which leads to the exporter's (importer's) currency invoicing. ${ }^{16}$ Thus, it is theoretically shown that the invoicing choice depends on the characteristics of the goods traded, which is consistent with the classical stylized fact $3 .{ }^{17}$ Some of machinery firms and electrical component firms in our sample, which export/sell competitive and highly differentiated products in the global market, clearly have a strong position to negotiate their invoicing currency with customers.

Hypothesis 4: Export products tend to be invoiced in the yen if they are highly differentiated and/or competitive.

\footnotetext{
${ }^{16}$ See Fukuda and Ji $(1994)$ and Sato $(1999,2003)$ for the empirical estimation of invoicing practices in Japanese exporters based on the firm's maximization behavior of expected profits.

${ }^{17}$ Johnson and Pick (1997) and Friberg (1998) extend theoretical model of the invoicing choice by analyzing in which condition the third currency invoicing is chosen. They show that not only the shape of the firm's profit function but also the exchange rate volatility (variance) against the importer's currency determines the choice of an invoice currency. While the above theoretical models are analyzed under the partial equilibrium framework, recent studies apply the general equilibrium model to the choice of an invoice currency, motivated by development of the New Open Economy Macroeconomics. For instance, Bacchetta and van Wincoop (2005) analyze the choice of invoice currency under the two-country general equilibrium model, and show that the producer's currency pricing (PCP) is chosen if the exporting firm's market share is larger in the destination market and if the economic size of exporting firm's country is larger
} 


\section{(iv) Exports from Asian production base to the US market}

Most of electrical machinery and electrical components firms that choose US dollar invoicing in exports to Asian countries have a particular trade structure in that their production subsidiaries exhibit a strong tendency to export their products to the US market or US firms. Under this production/distribution structure, the firms typically choose US dollar invoicing not only from the local subsidiaries in Asia to the US market but also from Japanese headquarters to the local subsidiaries in Asia, since it is advantageous to use the same currency in both transactions. ${ }^{18}$ This is a key to solve the second puzzle of the Japan's currency invoicing pattern, that is why the third currency, the US dollar is used in Japanese exports to Asia.

While exports to the United States previously accounted for the largest share in the total exports of Japan and Asian countries, it is now well recognized that intra-regional trade in Asia has become more important for these countries in recent years. Most sample firms, however, answered that the final destination market was the United States, since growing intra-regional trade was largely driven by processing trade. Whereas such an Asian trade structure is often pointed out, to our knowledge, it has never been tested empirically in the literature on invoicing choice. We construct a new variable and attempt empirical examination to take into account this aspect in the next sub-section.

Hypothesis 5: Japanese firms tend to choose US dollar invoicing in exports their products to the production subsidiaries in Asia when the production subsidiaries export high proportion of their products to the US market.

\section{5-2. Empirical Results}

\section{The Details of the Explanatory Variables}

The most commonly used explanatory variable for invoicing decision is the share of exports to a particular destination country in total exports, which is typically related to the choice of the destination country's currency invoicing or PTM (see, for instance, Goldberg and Tille, 2008 and Friberg and Wilander, 2008). Since we use a firm-level data and information, however, the above

\footnotetext{
${ }^{18}$ Moreover, to manage the exchange rate risk as efficiently as possible, some of major electrical machinery firms and electrical component firms adopt an efficient settlement strategy, the so-called "re-invoicing". Specifically, suppose a Japanese firm exports parts and components to its own production subsidiary in Asia to assemble them into finished goods and then the finished goods are exported directly from the subsidiary to the United States. The Japanese headquarter conducts accounting transactions by first purchasing the goods from the local subsidiary and then selling the goods to the US importers (possibly its own sales subsidiary in the United States). As long as all stages of accounting transactions are invoiced in US dollars, the Japanese firm can concentrate all exchange rate exposures against a single currency, the US dollar, at the headquarter. This re-invoicing strategy will impede the further use of the yen in Japan's trade with Asia.
} 
export share for each firm is hard to obtain. Alternatively, we use the "share of foreign sales in the region (North America, Europe, or Asia) in the total foreign sales." Since most exports of our sample firms are destined for overseas subsidiaries, the variable of the "share of foreign sales in the region" can be considered as a good proxy for the share of exports to a particular country/region.

In addition, we set up the following explanatory variables to empirically investigate the determinants of currency invoicing in Japanese exporting firms. ${ }^{19}$

The first and second explanatory variables are associated with the determinant (i) "intra- or inter-firm trade" (Hypothesis 1) and "exports through Sogo Shosha" (Hypothesis 2). We set a "dummy for the equity share of overseas subsidiary (>90\%)" that takes 1 if firm $i$ has overseas subsidiaries with more than $90 \%$ shares of equity in $k$ region, and 0 otherwise. ${ }^{20}$ Furthermore, we use a "dummy for trade through Sogo Shosha", because trade through Sogo Shosha is regarded as a factor of promoting yen invoiced trade.

The third explanatory variable is related with the determinant (ii) "cost of exchange rate hedging" (Hypothesis 3). We use a bid-ask spread of outright forward transactions between the yen and the importing country's currency as a straightforward proxy for the cost of exchange rate hedging.

The fourth explanatory variable is based on the determinant (iii) "the degree of market competition and differentiation of exporting products" (Hypothesis 4). As shown in A (c-3) of Appendix 3, three machinery firms and one electrical component firm answered that they tend to invoice their exports in the yen, because their products have strong export competitiveness. The four firms cited high market shares of their products as evidence of their products' strong export competitiveness. ${ }^{21}$ We use a "dummy for export competitiveness" that takes 1 for the four firms that have strong export competitiveness, and 0 otherwise.

The fifth explanatory variable is associated with the determinant (iv) "exports from Asian production subsidiaries to the US market" (Hypothesis 5). We set a "dummy for firm's plants in Asia to export" that takes 1 if the ratio of intra-firm sales from Asia (i.e., exports to subsidiaries outside Asia) to foreign sales in Asia (i.e., sales to Asian customers) is 50 percent or over, and 0 otherwise.

\section{Probit Estimation on the Determinants of Currency Invoicing}

We empirically test the hypothesis about the determinants of an invoice currency by using the above explanatory variables. Since the importer's currency invoicing is prevalent in Japanese exports to the advanced countries, which is the first puzzle of the Japan's currency invoicing pattern as

\footnotetext{
19 See Appendix 4 for the details of making these explanatory variables.

${ }^{20}$ See Appendix 5 for sample firm head office's equity share on local subsidiaries and segment information by region.

${ }^{21}$ In the interviews, based on the data on the global market share, it was confirmed that the export products of these firms accounted for a very large share in the world market.
} 
discussed in Section 4, our main interest is in analyzing in which currency Japanese exports to advanced countries are invoiced, the exporter's currency (the yen) or the importer's currency. We conduct probit estimation to analyze the determinants of currency invoicing, where the dependent variable is a binary variable that takes 1 if the importer's currency is used as the main invoice currency and 0 otherwise.

First, the results of estimation when exporting to the United States and Euro area are presented in columns (1) through (5) in Table 6. As a key determinant of currency invoicing, we use (i) the forward spread of the importer's currency against the yen, (ii) the share of foreign sales in the region, (iii) the head office's ownership (equity) share of local subsidiaries, and (iv) the dummy for export competitiveness. In columns (1) through (5), the forward spreads are negative and statistically significant at least at the 5 percent level, which indicates that the larger the hedging cost is, the less the importer's currency is used for trade invoicing. In columns (1) through (5), the effect of foreign sales in the region is also included to investigate whether the invoicing choice is affected by the extent of export dependence on the destination market. These are all positive but statistically insignificant in columns (3) and (5). Furthermore, to allow for the effect of intra-firm trade, the head office's equity share of local subsidiaries or its dummy ( $>90$ percent) are included in columns (2) through (5). These are all significantly positive at least at the 5 percent level, which strongly supports our hypothesized relationship that intra-firm trade facilitates importer's currency invoicing. Furthermore, the dummy for export competitiveness is included in columns (3) and (5), which indicates that the degree of export competitiveness negatively affects the extent of importer's currency invoicing.

Second, columns (6) through (8) show the results of probit estimation when including the advanced countries in North America and Europe (i.e., the United States, Canada, Euro area and UK) as a destination market. The estimated result is similar to the case of the United States and Euro area (columns (1) through (5)) except for the estimates of the share of foreign sales that are all positive but insignificant.

Overall, the results of the probit estimation reveal that the importer's currency is used as an invoice currency, if (i) the hedging cost of the importer's currency is lower, (ii) the headquarter has a high ownership (equity) share of the local subsidiaries, and (iii) export products are less differentiated or not competitive in the destination market. The second reason is particularly important in considering the first puzzle of the Japan's currency invoicing pattern. Since most Japanese exports to advanced countries are intra-firm transactions, the headquarter of Japanese exporting firms have a strong incentive to free their overseas subsidiaries from the exchange rate risk by invoicing in the local (importer's) currency. Such importer's currency invoicing is much more likely if the destination market is highly competitive or if the sample firm's export products are less competitive or differentiated. 
Table 6. Determinants of local currency invoicing

\begin{tabular}{|c|c|c|c|c|c|c|c|c|}
\hline \multirow[t]{2}{*}{ Sample } & \multicolumn{5}{|c|}{ 1. US and Euro Area } & \multicolumn{3}{|c|}{$\begin{array}{l}\text { 2. Developed countries/region in } \\
\text { North America and Europe } \\
\text { (US, Canada, Euro Area and UK) }\end{array}$} \\
\hline & (1) & (2) & (3) & (4) & (5) & (6) & (7) & (8) \\
\hline Cost of currency hedging & $\begin{array}{l}-6.045 * * \\
(2.844)\end{array}$ & $\begin{array}{c}-7.078 * * \\
(3.117)\end{array}$ & $\begin{array}{l}-6.506 * * \\
(3.779)\end{array}$ & $\begin{array}{c}-6.074 * * \\
(2.838)\end{array}$ & $\begin{array}{c}-4.778 * * \\
(3.675)\end{array}$ & $\begin{array}{l}-4.514^{*} \\
(2.628)\end{array}$ & $\begin{array}{r}-4.922 * \\
(2.584)\end{array}$ & $\begin{array}{c}-5.754 * * \\
(2.546)\end{array}$ \\
\hline Share of foreign sales in the region & $\begin{array}{l}1.012 * \\
(0.534)\end{array}$ & $\begin{array}{l}1.384 * * \\
(0.544)\end{array}$ & $\begin{array}{c}0.751 \\
(0.478)\end{array}$ & $\begin{array}{l}1.013^{* *} \\
(0.459)\end{array}$ & $\begin{array}{c}0.472 \\
(0.375)\end{array}$ & $\begin{array}{c}0.521 \\
(0.478)\end{array}$ & $\begin{array}{r}0.598 \\
(0.469) \\
\end{array}$ & $\begin{array}{c}0.198 \\
(0.470)\end{array}$ \\
\hline $\begin{array}{l}\text { Equity participation to overseas } \\
\text { subsidiary }\end{array}$ & & $\begin{array}{l}1.537 * * \\
(0.744)\end{array}$ & $\begin{array}{l}1.218^{* *} \\
(0.806)\end{array}$ & & & & & \\
\hline $\begin{array}{l}\text { Dummy for equity share of overseas } \\
\text { subsidiary }(>90 \%)\end{array}$ & & & & $\begin{array}{c}0.579 * * * \\
(0.216)\end{array}$ & $\begin{array}{l}0.627 * * \\
(0.257)\end{array}$ & & $\begin{array}{l}0.308^{*} \\
(0.178)\end{array}$ & $\begin{array}{l}0.296 * \\
(0.191)\end{array}$ \\
\hline Dummy for export competitiveness & & & $\begin{array}{l}-0.526 * * \\
(0.242)\end{array}$ & & $\begin{array}{c}-0.434 * * \\
(0.260)\end{array}$ & & & $\begin{array}{c}-0.492 * * * \\
(0.179)\end{array}$ \\
\hline \# of Observations & 43 & 43 & 43 & 43 & 43 & 61 & 61 & 61 \\
\hline
\end{tabular}

1) Method: Probit estimation. The dependent variable is a binary variable that takes 1 if the importer's currency is the main invoice currency and 0 otherwise.

2) Each regression equation includes a constant term. The results of marginal effects are reported. Standard errors are in parenthesis.

3) The asterisk(s), ***,**, and * mean that the coefficient is statistically significant at 1 percent, 5 percent, and 10 percent level, respectively.

We next conduct the similar estimation focusing on Asian economies where Japanese firms have built a regional production network. In this estimation, the destinations include the following eight economies: Mainland China, Korea, Hong Kong, Singapore, Malaysia, Indonesia, Thailand and the Philippines. Our main interest is in solving the second puzzle of the Japan's currency invoicing pattern, i.e., why US dollar invoicing is larger than yen invoicing in Japan's exports to Asia. In conducting probit estimation, the dependent variable for columns (1) through (5) in Table 7 is a binary variable that takes 1 if the US dollar is used as the main invoice currency and 0 otherwise. In addition, columns (6) through (10) in Table 7 present the case where the dependent variable is a binary variable that takes 1 if the yen is used as the main invoice currency.

Let us first look at the results of estimation reported in columns (1) through (5) of Table 7 where the determinants of US dollar invoicing are analyzed. First, in contrast to the results of the previous estimation for advanced countries (Table 6), forward spreads do not have significant effect on the choice of an invoice currency. The dummy for the head office's ownership (equity) share of local subsidiaries affects positively the US dollar invoicing choice at the 1 percent significance level in columns (1) through (5), which implies that Japanese firms, which have local subsidiaries in Asia with more than 90 percent equity share, tend to choose US dollar invoicing. 
Table 7. Determinants of currency invoicing in Japan's exports to Asian economies

\begin{tabular}{|l|c|c|c|c|c|c|c|c|c|c|}
\hline \multicolumn{1}{|c|}{ Dependet Variable } & \multicolumn{7}{|c|}{ A binary variable that takes 1 if USD is the main invoice } & \multicolumn{3}{c|}{ A binary variable that takes 1 if JPY is the main invoice } \\
currency
\end{tabular}

1) Method: Probit estimation. The dependent variable is a binary variable that takes 1 if the US dollar (columns (1) through (5)) or the yen (columns (6) through (10)) is the main invoice currency and 0 otherwise.

2) Each regression equation includes a constant term. The results of marginal effects are reported. Standard errors are in parenthesis.

3) The asterisk(s), ***, **, and * mean that the coefficient is statistically significant at 1 percent, 5 percent, and 10 percent level, respectively.

Second, the dummy for trade through Sogo Shosha consistently indicates a negative impact on the US dollar invoicing, though the coefficient is significantly negative at the 5 percent level only in columns (3) and (5).

Third, whereas the share of foreign sales in Asia does not have any significant effect on the invoicing choice (columns (1), (2) and (4)), the share of foreign sales in North America positively affects the US dollar invoicing at the 5 percent significance level in columns (1) through (5). This result is somewhat puzzling, because it shows that the larger the firm's sales in North America (mainly the United States), the more the US dollar will be used in the firm's exports from Japan to Asia. The clue of understanding this puzzling relationship is to understand the definition of the data on the "foreign sales in the region". ${ }^{22}$ This foreign sales variable covers the exports of Japanese firm's

\footnotetext{
${ }^{22}$ Assuming that North America is identical to the United States for simplicity, let us consider the definition of "the firm $i$ 's foreign sales in the United States". This foreign sales variable covers (i) the exports of the firm $i$ from Japan to the United States (i.e., customers in the United States except for the firm $i$ 's subsidiaries), (ii) the exports of the firm $i$ 's overseas (but non-US) subsidiaries to the United States, and (iii) the local sales of firm $i$ 's subsidiaries in the United States. Since, as discussed earlier, major Japanese firms tend to export their products to the local subsidiaries, the export channel (i) does not account for a large share in the total foreign sales in the United States. Based on the consolidated accounting, the firm $i$ 's exports from Japan to the local subsidiaries in the United States are not directly counted in "the firm $i$ 's foreign sales in the United States", but are indirectly allowed for by the channel (iii). As reported in, for instance, METI, White Paper 2009, Asian countries export a large
} 
subsidiaries in Asia to the United States and other external countries. Given the triangular trade where the Japanese production subsidiaries in Asia import intermediate goods from the Japanese head office and export finished products to the United States, US dollar invoicing will be chosen at each stage of trade transactions. The positive and significant coefficient of the foreign sales in North America may show the invoicing choice in the above triangular trade.

To confirm the effect of the above triangular trade on US dollar invoicing, the "dummy for plants in Asia to export" (Asian plant dummy) is also included in columns (4) and (5) as an explanatory variable that represents the exports from Japanese production subsidiaries in Asia to the US market. ${ }^{23}$ The coefficient of this Asian plant dummy is positive and statistically significant at the 5 percent level in column (4) and at the 10 percent level in column (5). In columns (2) and (3) where the dummy for export competitiveness is included, coefficients of export competitiveness dummy has negative signs though their significant levels are marginal around the 10 percent level. These results do support our hypothesized relationship that exports from Asian production base to the US market facilitate US dollar invoicing in Japanese exports to Asian countries.

Next, the determinants of yen invoicing are analyzed using the same data set. The results reported in columns (5) through (10) are consistent with those presented in columns (1) through (5). The forward spread does not have significant effect on the extent of yen invoicing. The dummy for the head office's ownership (equity) share of local subsidiaries has negative and significant influences on the yen invoicing choice. The dummy for Sogo Shosha exhibits positive and statistically significant coefficients in all cases. Although it is said that the role of Sogo Shoha has been declining in Japanese exports, our interview analysis has shown that exports through Sogo Shosha still play a certain role when the destination is Asia and other developing countries. The results of our estimation suggest that the share of yen invoicing will be increasing when exporting through Sogo Shosha. While the coefficient of Asian plant dummy is not statistically significant, the dummy for export competitiveness shows all positive and significant coefficients, which suggests that Japan's exports of differentiated products to Asia facilitate yen invoicing transactions.

In summary, the second puzzle of the Japan's invoicing pattern can be explained by the growing intra-firm exports from Japan to Asian subsidiaries based on their regional production network combined with the fact that Japanese production subsidiaries in Asia tend to export a large proportion to the US market.

amount of finished products to the United States after processing and assembling intermediate goods through intra-Asian trade including trade between Japan and Asian subsidiaries, which is covered by the channel (ii).

${ }^{23}$ See Appendices 4 and 5 for the details of the Asian plant dummy. 


\section{Concluding Remarks}

This paper empirically examines a firm-level pricing behavior of Japanese exports to propose new determinants of invoicing behavior and to present new evidence on traditional and newly proposed determinants. We interviewed 23 Japanese representative exporting firms to collect information on their currency invoicing behavior and also on their explicit policy/strategy of choosing their invoice currency. Through interviews, we found that Japanese electronics and automobile companies have a strong tendency to choose local currency invoicing in exports to advanced countries, while U.S. dollar invoicing is largely used when exporting to Asian countries, especially in exporting electronics products. Such an invoicing strategy aims at stabilizing the local currency (U.S. dollar) price of their export products in local markets, which conforms to the pricing-to-market behavior discussed in the literature.

This paper proposes the new determinants and hypotheses of an invoice currency and tests those hypotheses using a newly-constructed firm-level data set. Our novel findings are three-fold. First, importer's currency invoicing is prevalent in Japanese exports to advanced countries, because most of their exports are destined for local subsidiaries that face severe competition in the local markets. In this case, Japanese parent firms have a strong tendency to take an exchange rate risk by invoicing in the importer's currency, which is consistent with the PTM behavior discussed in the literature. It also makes sense to concentrate currency risk at the headquarter, since it is better equipped with risk management expertise and with scale economies. Second, Japanese firms that export highly differentiated products or have a dominant share in global markets tend to choose yen invoicing even in exports to advanced countries. Third, although Japanese firms have shifted their production bases to Asian countries, exports from these Asian bases tend to be invoiced in US dollars as long as the final destination market is the United States, which results in the US dollar invoicing even in exports from Japanese head office to production subsidiaries in Asia. Thus, a smaller share of yen invoicing in Japanese exports even in the 2000s is due to the growing intra-firm trade promoted by active overseas operations of Japanese electronics firms combined with its final destination being the US markets.

While Japan's production networks in Asia reinforce its unique pattern of currency invoicing, country-specific foreign exchange regulations in Asia also cause US dollar invoicing in Japanese exports to Asia. Since the Asian currency crisis in 1997, foreign exchange regulations and controls in Asian countries have been strengthened and reinforced the use of US dollars in Asia. 


\section{References}

Bacchetta, Philippe and Eric van Wincoop, 2005, A Theory of the Currency Denomination of International Trade, Journal of International Economics, 67(2), pp.295-319.

Deutsche Bundesbank, 1991. "The Significance of the Deutsche Mark as an Invoicing Currency in Foreign Trade," Monthly Report, November, pp.40-44.

Donnenfeld, Shabtai and Itzhak Zilcha, 1991, "Pricing of Exports and Exchange Rate Uncertainty," Review of International Economics, 32, pp.1009-1022.

Donnenfeld, Shabtai and Alfred Haug, 2003, "Currency Invoicing in International Trade: an Empirical Investigation," Review of International Economics, 11(2), pp.332-345.

Donnenfeld, Shabtai and Alfred Haug, 2008, "Currency Invoicing of US Imports," International Journal of Finance and Economics, 13(2), pp.184-198.

Friberg, Richard. 1998 "In which Currency Should Exporters Set their Prices?" Journal of International Economics, 45(1), pp.59-76.

Friberg, Richard and Fredrik Wilander, 2008, "The Currency Denomination of Exports---A Questionnaire Study," Journal of International Economics, 75, pp.54-69.

Fukuda, Shin-ichi and Ji Cong, 1994, "On the Choice of Invoice Currency by Japanese Exporters: The PTM Approach,” Journal of the Japanese and International Economies, 8, pp.511-529.

Giovannini, Alberto, 1988, "Exchange Rates and Traded Goods Prices," Journal of International Economics, 24, pp.45-68.

Goldberg, Linda S. and Cédric Tille, 2008, "Vehicle Currency Use in International Trade," Journal of International Economics, 76(2), pp.177-192.

Goldberg, Linda S. and Cédric Tille, 2009, "Micro, Macro, and Strategic Forces in International Trade Invoicing,” NBER Working Paper No.15470, National Bureau of Economic Research.

Grassman, Sven, 1973, “A Fundamental Symmetry in International Payments.” Journal of 
International Economics, 3, pp.105-16.

Grassman, Sven, 1976, "Currency Distribution and Forward Cover in Foreign Trade," Journal of International Economics, 6, pp.215-221.

Ito, Takatoshi, 1993. "The Yen and the International Monetary System,” in C.F. Bergsten and M. Noland, eds., Pacific Dynamism and the International Economic System, (Washington, D.C.: Institute of International Economics), pp.299-322.

Johnson, Martin and Daniel Pick, 1997, "Currency Quandary: The Choice of Invoicing Currency under Exchange-Rate Uncertainty," Review of International Economics, 5(1), pp.118-128.

Kawai, Masahiro, 1996. "The Japanese Yen as an International Currency: Performance and Prospects," in Ryuzo Sato, Rama Ramachandran, and Hajime Hori, eds., Organization, Performance, and Equity: Perspectives on the Japanese Economy, (Massachusetts: Kluwer Academic Publishers), pp.305-355.

Kamps, Annette, 2006, “The Euro as Invoicing Currency in International Trade," ECB Working Paper No.665, European Central Bank.

Knetter, Michael M., 1989, "Price Discrimination by U.S. and German Exporters," American Economic Review, 79(1), pp.198-210.

Knetter, Michael M., 1993. "International Comparison of Pricing-to-Market Behavior," American Economic Review, 83, pp.473-486.

Krugman, Paul, 1980, "Vehicle Currencies and the Structure of International Exchange," Journal of Money, Credit and Banking, 12, pp.513-526.

Krugman, Paul, 1984, "The International Role of the Dollar: Theory and Prospect," in John Bilson and Richard Marston, eds., Exchange Rate Theory and Practice, Chicago: University of Chicago Press, pp.261-278.

Krugman, Paul R., 1987. "Pricing to Market When the Exchange Rate Changes," in Sven W. Arndt and J. David Richardson, eds., Real-Financial Linkage among the Open Economies, (Cambridge: MIT Press), pp.49-70. 
Ligthart, Jenny and Jorge A. da Silva, 2007, "Currency Invoicing in International Trade: A Panel Data Approach," Tilburg University Discussion Paper, No.2007-25.

Marston, Richard C., 1990. "Pricing to Market in Japanese Manufacturing," Journal of International Economics, 29, pp.217-236.

Marston, Richard C., 1991. "Pricing Behavior in Japanese and US Manufacturing," in P. Krugman (ed.), The US and Japan: Trade and Investment, University of Chicago Press.

McKinnon, Ronald, I., 1979, Money in International Exchange: The Convertible Currency System, Oxford University Press.

Ogawa, Eiji, and Junko Shimizu, 2005, “A Deviation Measurement for Coordinated Exchange Rate Policies in East Asia," RIETI Discussion Paper, 05-E-017.

Ogawa, Eiji, and Junko Shimizu, 2007, "Progress toward a Common Currency Basket System in East Asia," RIETI Discussion Paper, 07-E-002.

Page, S. A. B., 1977, "Currency of Invoicing in Merchandise Trade," National Institute Economic Review, 33, pp.1241-1264.

Page, S. A. B., 1981, "The Choice of Invoicing Currency in Merchandise Trade," National Institute Economic Review, 85, pp.60-72.

Parsons, Craig and Kiyotaka Sato, 2008, "New Estimates of Exchange Rate Pass-Through in Japanese Exports," International Journal of Finance and Economics, 13(2), pp.174-183.

Sato, Kiyotaka, 1999, "The International Use of the Japanese Yen: The Case of Japan's Trade with East Asia," The World Economy, 22(4), pp.547-584.

Sato, Kiyotaka, 2003, "Currency Invoicing in Japanese Exports to East Asia: Implications for the Yen Internationalization,” Asian Economic Journal, 17(2), pp.129-154.

Takagi, Shinji and Yushi Yoshida, 2001, "Exchange Rate Movements and Tradable Goods Prices in East Asia: An Analysis Based on Japanese Customs Data, 1988-1999," IMF Staff Papers, 48(2), 
pp.266-289.

Tavlas, George S., 1997. "The International Use of the US Dollar: An Optimum Currency Area Perspective," The World Economy, Vol.20, No.6, pp.709-747.

Tavlas, George S. and Yuzuru Ozeki, 1992. The Internationalization of Currencies: An Appraisal of the Japanese Yen, Occasional Paper, 90, (Washington, D.C.: International Monetary Fund). 


\section{Appendix 1: Currency Invoicing in Japanese Imports}

Figure A1: Currency Invoicing of Japanese Imports: Yen and the US Dollar (\%)
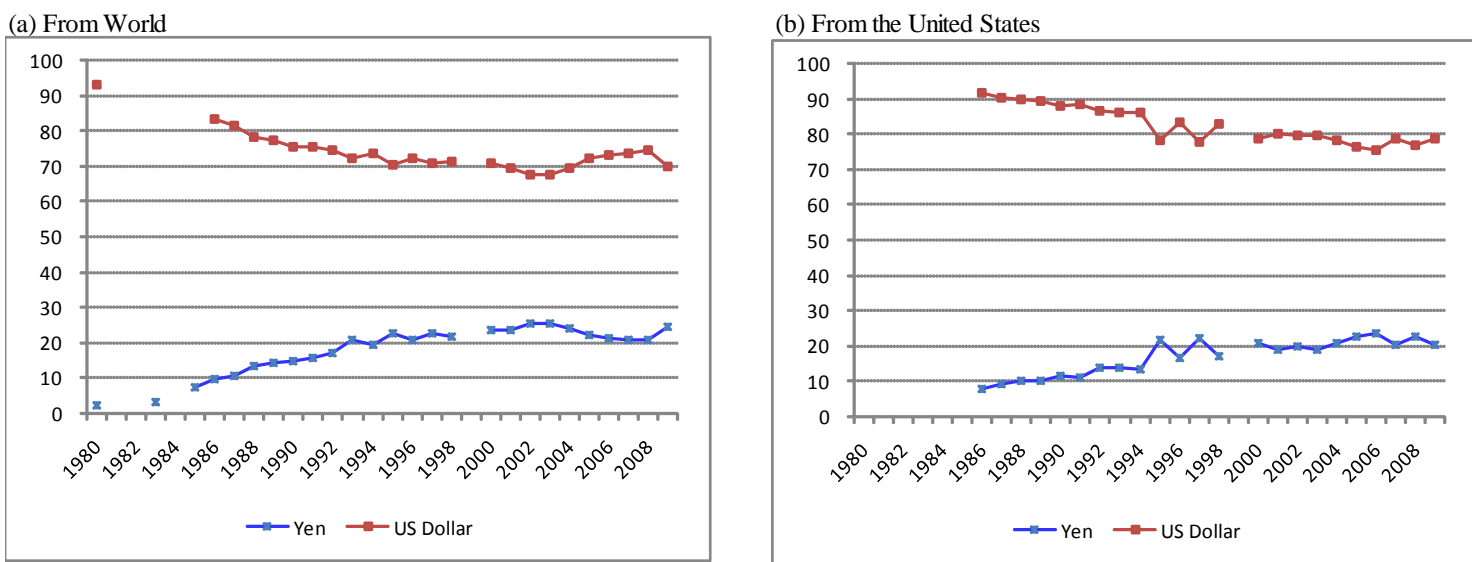

(c) From EU (EC)
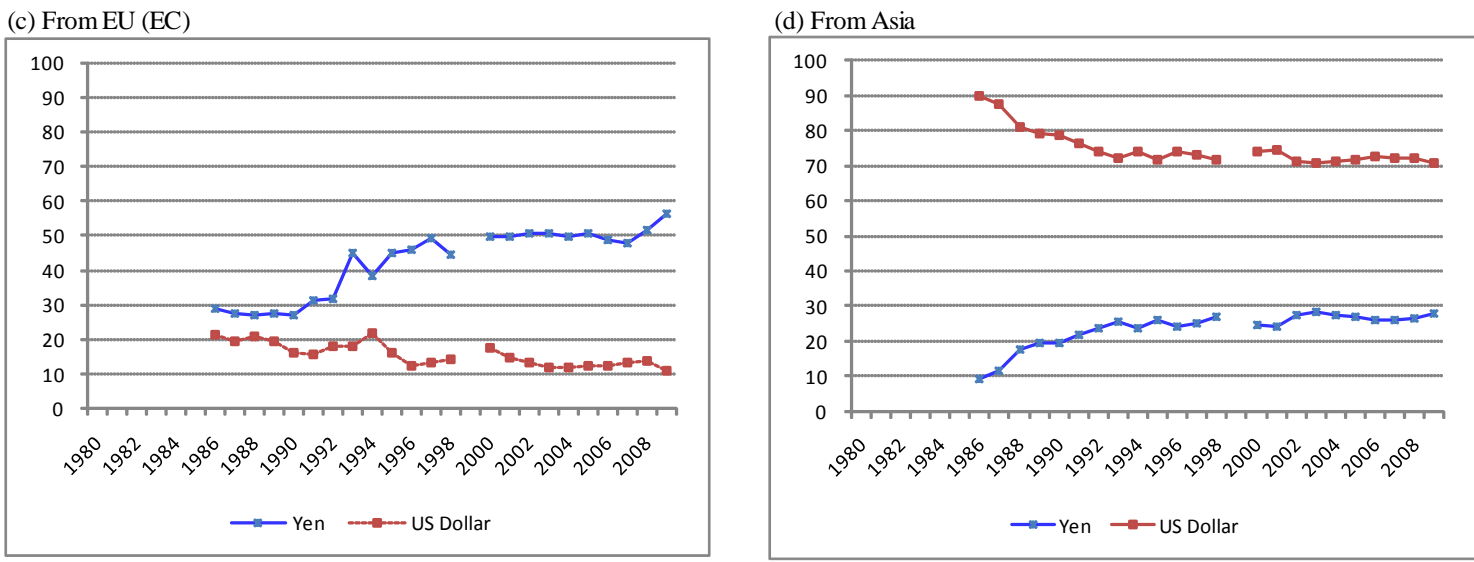

Notes: The data for 1999 is not available. For imports from the world, the data on yen invoicing is not available for 1981, 1982 and 1984, and the data on US dollar invoicing is not available for 1981-85. The 1986 data is the fiscal year data. The September data is used for 1992-97, the March data for 1998, and the 2nd half of the year data for 2000-09.

Source: MITI, Yunyu Shonin Todokede Hokokusho (Import Approval Notification Report); MITI, Hokokushorei ni Motozuku Hokoku (Report Based on Report Guidance); MITI, Yunyu Hokoku Tokei (Import Report Statistics); MITI, Yunyu Hokukosho Tukadate Doko (Import Currency Invoicing Report); MITI, Yunyu Kessai Tsukadate Doko Chosa (Import Settlement Currency Invoicing).

Figure A1 shows the share of both yen and US dollar invoicing in Japan's imports from 1980 to 2009. In Japan's imports from the world, the share of yen invoicing increased gradually from 2.4 percent in 1980 to 20 percent in 1993, but it did not increase much from then on and remained at 24.6 percent even in 2009. The US dollar is most used in Japanese imports and its share was 70.1 percent even in 2009. As the classic stylized fact 3 suggests, the more imports of crude oils and raw materials are, the higher the share of the US dollar is in Japan's imports. Whereas Japan has long been 
dependent heavily on imports of oils and raw materials, Japan's import pattern has structurally changed in recent years with a substantial increase in procurements of manufactured products from Asian countries. As the regional integration has been deepening and production network has been developed further by Japanese firms, the use of the yen can be expected to increase in Japan's imports from Asia. Figure A1(d) shows, however, that more than 70 percent of imports from Asia are invoiced in US dollars and the share of yen invoicing has never exceeded 30 percent even in the 2000s. It is confirmed that the US dollar is still dominantly used in trade between Japan and Asia. 


\section{Appendix 2: Currency Invoicing and the Share of Foreign Sales}

For further investigation of the possible relationship between the invoicing choice and the foreign sales by region, we plot the data in Figures A2 to A4, where the "share of currency invoicing in exports" (US dollar, Euro, and Japanese yen) for each of 21 sample firms is placed on the vertical axis and the "share of foreign sales " (North America, Europe, and Asia) on the horizontal axis. A cross-section OLS is also conducted and the regression line as well as the 45 degree line is presented in the figures.

Figure A2. Share of USD Invoicing and Foreign Sales in North America

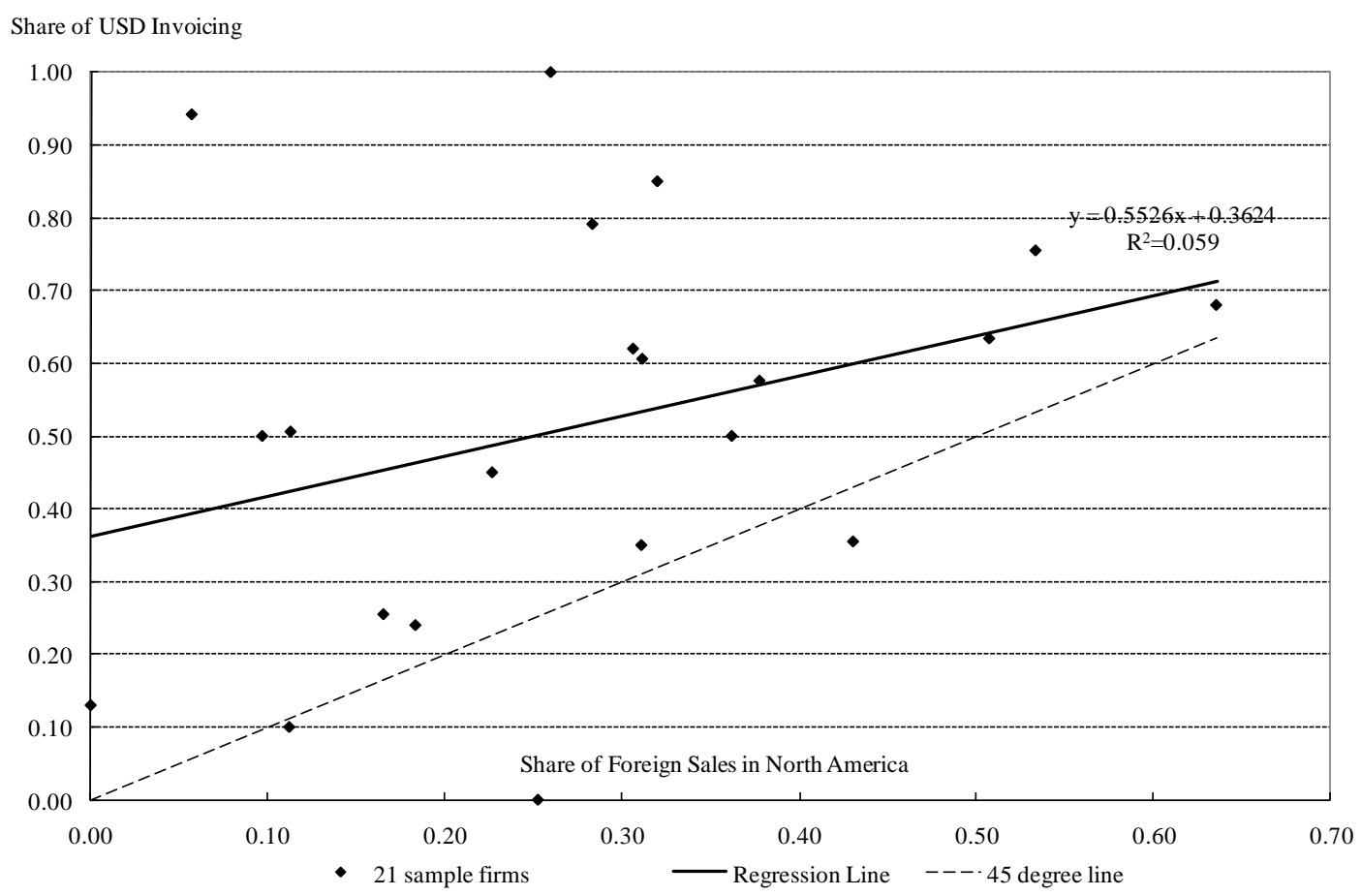

Figure A2 shows the relationship between the share of US dollar invoicing and the share of foreign sales in North America. Assuming that the size of the US market is dominant in North America, the larger the share of foreign sales in North America, the higher the share of US dollar invoicing is. If the US dollar does not play a role of vehicle currency in Japanese trade with other region, all points in Figure A2 would lie along a 45 degree line (dotted line) ${ }^{24}$.

Interestingly, most sample companies are distributed at the upper side of the 45 degree line. A regression line (solid line) has the positive and statistically significant intercept (0.36) while its

\footnotetext{
${ }^{24}$ Figure A2 in this paper is similar to Goldberg and Tille (2008, Fig.1) that show the relationship between the share of US dollar invoicing in export of each sample country and the share exports to the United States in the total exports of the country concerned.
} 
estimated slope coefficient is positive (0.55) but not statistically significant. This evidence strongly suggests that US dollar invoicing is prevalent not only in exports to North America (or US) but also other countries. This observation is consistent with the view that there is a vehicle currency role in the US dollar. Moreover, although not explicitly shown in Figure A2 to assure anonymity of sampled firms, most electrical machinery and electrical component companies are distributed at the far upper side of the 45 degree line, which implies that US dollar is globally used especially in the electronics trade.

Figure A3. Share of Euro Invoicing and Foreign Sales in Europe

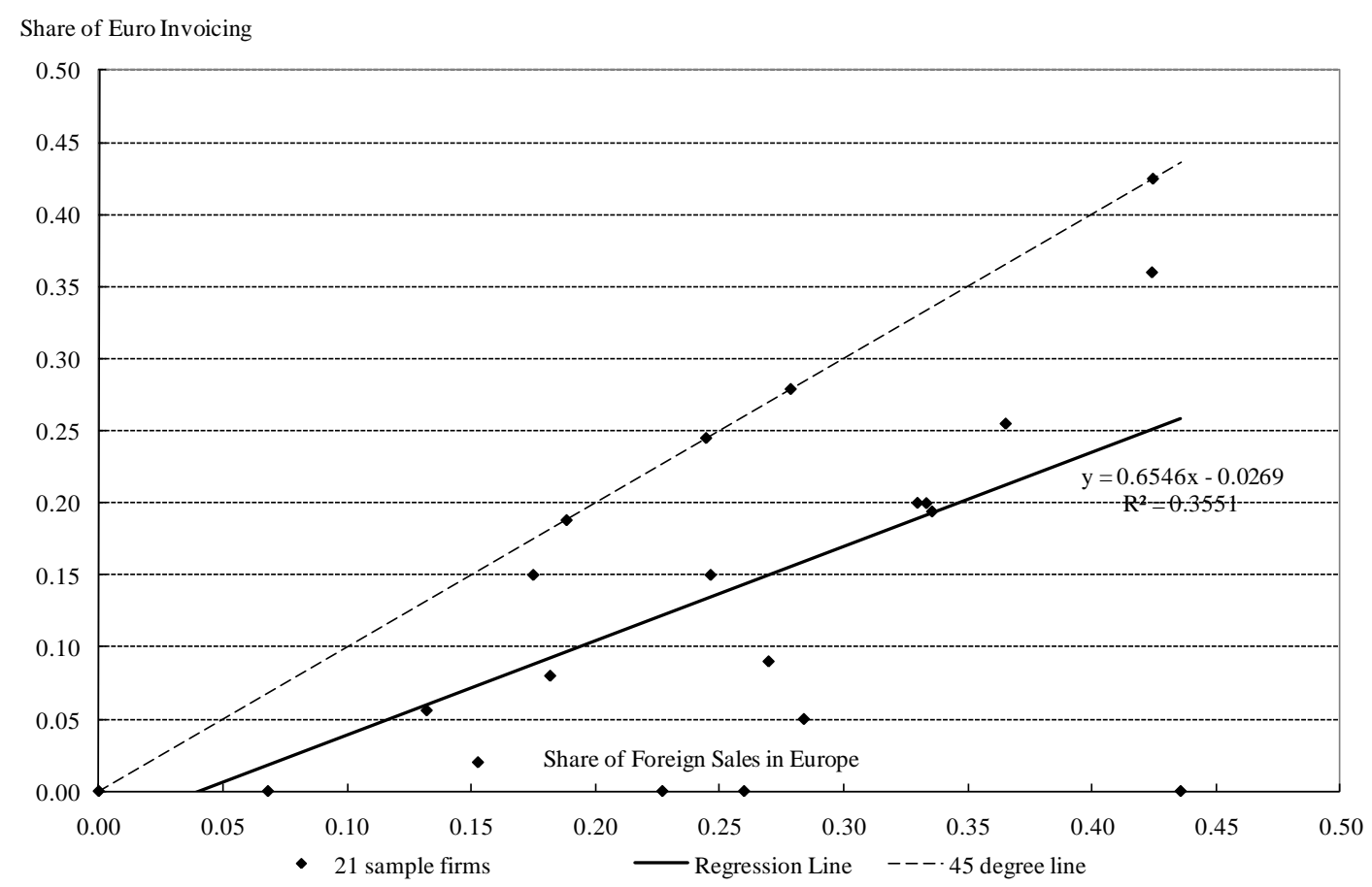

Figure A3 shows the relationship between the share of Euro invoicing and the share of foreign sales in Europe. In contrast to Figure A2, all sample firms are distributed on or below the 45 degree line. A regression line has a positive slope coefficient (0.65) that is statistically significant at the $1 \%$ level and also has an insignificant constant term (-0.02). This result indicates that Japanese firms tend to conduct the PTM behavior in exports to the Euro area by invoicing in the euro. 
Figure A4. Share of Yen Invoicing and Foreign Sales in Asia

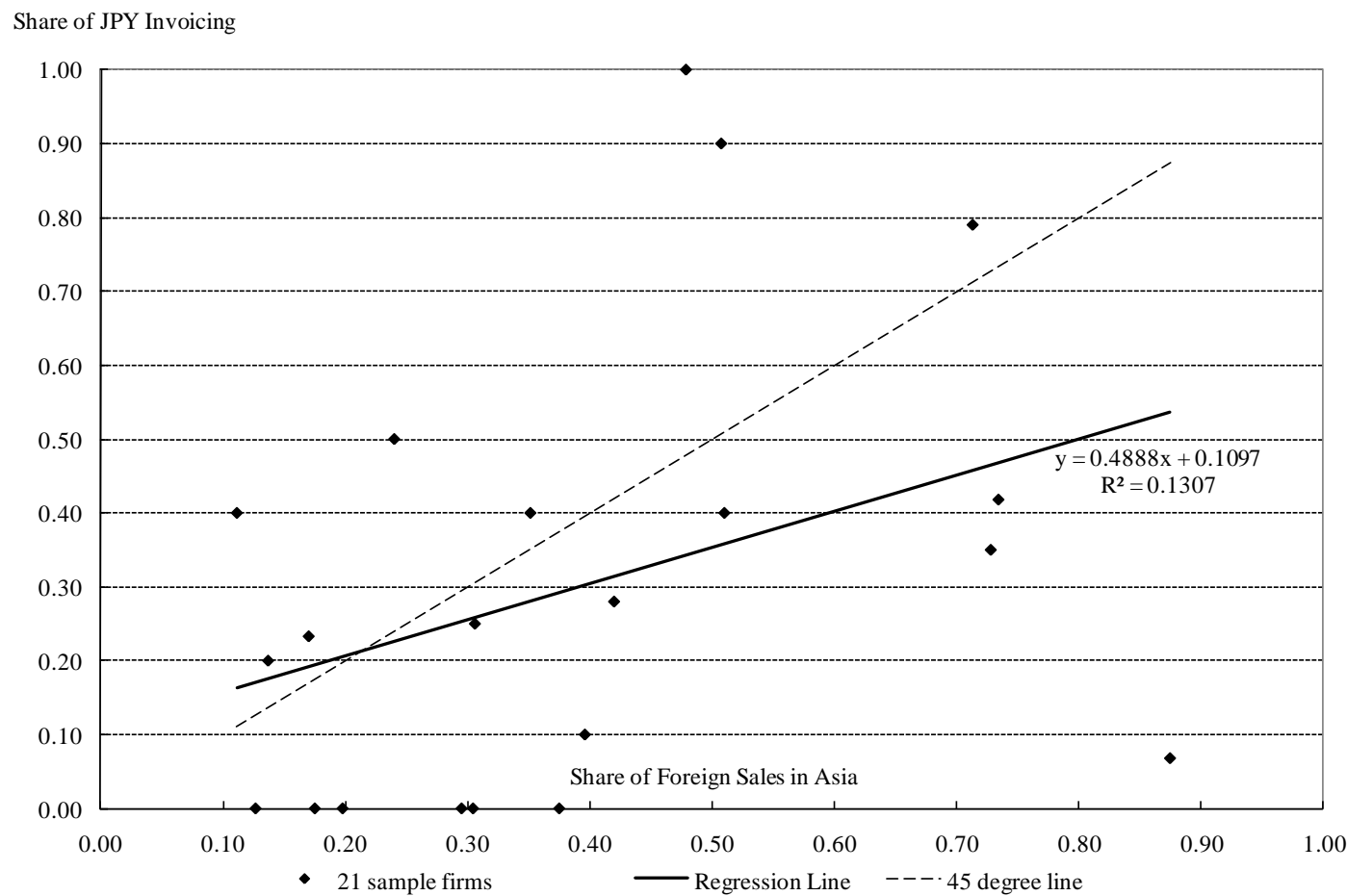

Figure A4 shows the relationship between the share of yen invoicing and the share of foreign sales in Asia. As it is easily recognized, there is almost no relationship between two shares. While the regression line has positive intercept $(0.10)$ and slope $(0.48)$, they are not different from zero at any significant level. Though not explicitly shown, the automobile and machinery companies exhibit a high share of yen invoicing, while the electrical machinery and electrical component companies tend to have an extremely lower share of yen invoicing, which is consistent with Table 3. 


\section{Appendix 3: Firm's Policy of Currency Invoicing and Exchange Rate Risk Management}

Number of firms to answer "yes"

\begin{tabular}{|c|c|c|c|c|c|}
\hline & $\begin{array}{l}\text { All sample } \\
\text { firms }\end{array}$ & Automobile & $\begin{array}{c}\text { Electrical } \\
\text { machinery }\end{array}$ & Machinery & $\begin{array}{l}\text { Electrical } \\
\text { components }\end{array}$ \\
\hline Number of sample firms & 23 & 9 & 7 & 3 & 4 \\
\hline \multicolumn{6}{|l|}{ A. Reasons for choice of invoice currency } \\
\hline \multicolumn{6}{|c|}{ (a) Reasons why the company chooses the local currency invoicing for exports to developed countries } \\
\hline (a-1) Trade partners in North America and Europe are local & & & & & \\
\hline $\begin{array}{l}\text { subsidiaries with high equity participation from the home office in } \\
\text { Japan }\end{array}$ & 9 & 6 & & 2 & 1 \\
\hline $\begin{array}{l}\text { (a-2) To gather exchange rate risk into the head office in Japan and } \\
\text { overseas subsidiaries with ability of exchange rate risk management }\end{array}$ & 7 & 2 & 2 & & 3 \\
\hline (a-3) High degree of the market competition in developed countries & 2 & 1 & 1 & & \\
\hline $\begin{array}{l}\text { (a-4) Increasing share of costs in terms of local currency due to } \\
\text { extended localization of production }\end{array}$ & 1 & & & 1 & \\
\hline
\end{tabular}

(b-1) Trade partners in Asia are local subsidiaries or joint venture with low equity participation from the home office in Japan

(b-2) High transaction cost of Asian local currency due to various regulations and restrictions

(b-3) Local subsidiaries in Asia are able to manage exchange rate risk
4

3

1

4

1
1

1

(c) Reasons why the company chooses the Yen invoicing for exports

\begin{tabular}{|c|c|c|c|c|c|}
\hline $\begin{array}{l}\text { (c-1) Yen invoicing is common in the case of exports through } \\
\text { Japanese trading companies }\end{array}$ & 6 & 4 & 2 & & \\
\hline $\begin{array}{l}\text { (c-2) Dominate share of costs in terms of Yen due to high } \\
\text { concentration of R\&D activity and key parts production in Japan }\end{array}$ & 2 & & & 1 & 1 \\
\hline $\begin{array}{l}\text { (c-3) Explicit policy for choosing yen imvoicing due to strong } \\
\text { bargaining power and high competitiveness based on high market } \\
\text { share of company's product }\end{array}$ & 4 & & & 3 & 1 \\
\hline (c-4) Customers demand Yen invoicing & 3 & & & 1 & 2 \\
\hline \multicolumn{6}{|l|}{ d) Reasons why the company chooses the US dollar invoicing for exports } \\
\hline (d-1) Transaction costs of US dollar are lowest among currencies & 5 & 3 & 1 & 1 & \\
\hline $\begin{array}{l}\text { (d-2) US dollar invoicing is more preferable that Yen invoicing in the } \\
\text { US dollar-peg countries }\end{array}$ & 1 & & 1 & & \\
\hline $\begin{array}{l}\text { (d-3) Electronic goods and natural resources are usually traded by } \\
\text { US dollar in the international markets. }\end{array}$ & 5 & & 1 & 2 & 2 \\
\hline $\begin{array}{l}\text { (d-4) Trades with processing trading ports like Singapore and Hong } \\
\text { Kong are settled by the US dollar }\end{array}$ & 1 & & 1 & & \\
\hline $\begin{array}{l}\text { (d-5) Unifying the invoice currencies to US dollar to exploit the } \\
\text { merits of marry and netting in the company }\end{array}$ & 6 & 2 & 3 & & 1 \\
\hline $\begin{array}{l}\text { (d-6) Trade structure exporting from production subsidiaries in Asia } \\
\text { to USA / US firms }\end{array}$ & 4 & & 3 & & 1 \\
\hline
\end{tabular}


Appendix 3: Firm's Policy of Currency Invoicing and Exchange Rate Risk Management (cont'd)

\begin{tabular}{lcccccc}
\hline & \multicolumn{3}{c}{ Number of firms to answer "yes" } \\
\hline & $\begin{array}{c}\text { All sample } \\
\text { firms }\end{array}$ & Automobile & $\begin{array}{c}\text { Electrical } \\
\text { machinery }\end{array}$ & Machinery & $\begin{array}{c}\text { Electrical } \\
\text { components }\end{array}$ \\
\hline Number of sample firms & 23 & 9 & 7 & 3 & 4 \\
\hline
\end{tabular}

B. Exchange rate risk management

(e) Hedging strategy

\begin{tabular}{|c|c|c|c|c|c|}
\hline (e-1) Rarely used & 5 & 3 & 1 & 1 & \\
\hline (e-2) Mainly exchange rate forward & 13 & 5 & 4 & 1 & 3 \\
\hline (e-3) Mainly exchange rate option and other derivatives & 2 & 1 & & 1 & \\
\hline
\end{tabular}

(f) Extent of exposure covered by the hedging

\begin{tabular}{|c|c|c|c|c|}
\hline (f-1) Full hedging & 3 & 1 & 1 & 1 \\
\hline (f-2) $70 \%$ & 2 & 1 & 1 & \\
\hline (f-3) $50 \%$ & 3 & 1 & 1 & 1 \\
\hline (f-4) Depending on the market conditions & 1 & 1 & & \\
\hline
\end{tabular}

(g) Length of period covered by the hedging

$\begin{array}{llll}\text { (g-1) 1-2 months } & 1 & 1 & \\ \text { (g-2) 3-6 months } & 3 & 1 & 2 \\ \text { (g-3) half year } & 2 & 2\end{array}$

(h) Marry and netting

$\begin{array}{llllll}\text { (h-1) We use marry and/or netting to manage exchange } & 17 & 6 & 7 & 1\end{array}$
rate risk

C. Price setting

(i) Rule of price setting when substantial exchange rate fluctuations

(i-1) No, we do not have the explicit rule.

$13-5$

(i-2) Yes, we have the explicit rule.

42

(j) Product differentiation and market share

(j-1) High degree of product differentiation and dominant share of market enable us to accommodate exchange rate 6

3

3

1

1

1




\section{Appendix 4: The details of the explanatory variables}

The following are used as the explanatory variables in our probit estimation.

\section{(1) Firm $i$ 's equity share of overseas subsidiary in the $k$ destination country (region)}

It is a proxy for the share of intra-firm trade in firm $i$ 's exports from Japan to each country (region). We first scrutinize the list of consolidated subsidiaries (companies) in each company's annual financial statements (as of FY2006 or 2007) to investigate whether each firm owns equity method affiliates in respective destinations If overseas subsidiaries are found in the destination, we use the equity share held by its parent firm (head office) in Japan as a proxy for the share of intra-firm trade between Japan and the destination country (region). If there are two or more subsidiaries in one destination country (region), we use the average of their equity shares. We also set the "dummy for equity share of overseas subsidiary ( $>90 \%$ )" that takes 1 if firm $i$ has overseas subsidiaries in the $k$ country (region) with more than $90 \%$ equity shares, and 0 otherwise. Appendix 5 summarizes the status of equity share of overseas subsidiaries held by head office in Japan.

\section{(2) Dummy for trade through Sogo Shosha}

The General Trading Company is called "Sogo Shosha" in Japanese. Since the data on the share of exports through Sogo Shosha by country/region is not available, we obtained the information from the annual financial statements on the fiscal-year-end balance of trade accounts receivable. We set the "dummy for trade through Sogo Shosha" that takes 1 if we find the name of Sogo Shosha in the top 5 of balance of trade accounts receivable in the fiscal-year-end, and 0 otherwise.

\section{(3) Firm $i$ 's share of foreign sales to region $k$ ( $k=$ North America, Asia)}

We use the share of firm $i$ 's foreign sales in region $k$ 's market in its total foreign sales as a proxy for the share of the region $k$ in the firm i's export destinations. Appendix 5 summarizes the segment information by region and foreign sales in the financial statement

\section{(4) $k$ country/region currency's forward spreads $(\%)$ as of Feb.2008}

As a proxy for the cost of exchange rate hedging, we use a bid-ask spread of forward outright transactions between the yen and the destination country's currency. The bid-ask spread is calculated in percentage of the transaction basis by using the actual market bid-ask spreads of both spot and forward swap transactions as follows:

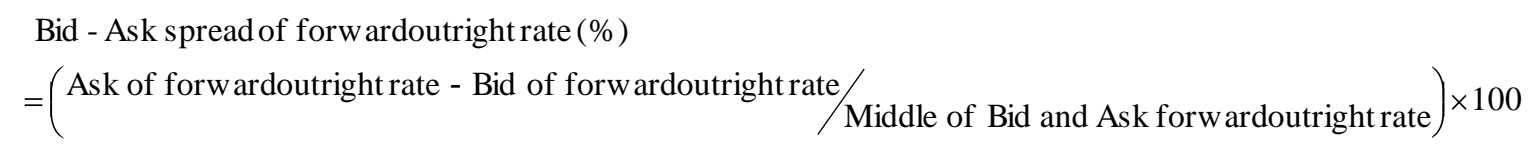


All data of spot and forward swap rates (3 month) were obtained in the whole trading date of April 2008. All data were downloaded from Bloomberg.

\section{(5) Dummy for firm i's plants in Asia to export}

Combined with the explanatory variable (3), i.e. the firm $i$ 's share of foreign sales in North America, we use a new dummy variable to take into account the firm that exports its products from subsidiaries in Asia to the final destination, the United States. We set the "dummy for firm's plants in Asia to export" that takes 1 if the ratio of intra-firm sales from Asia (i.e., exports to subsidiaries outside Asia) to foreign sales in Asia (i.e., sales to Asian customers) is $50 \%$ or over, and 0 otherwise.

\section{(6) Dummy for firm $i$ 's export competitiveness}

This dummy variable takes 1 if the firm $i$ is objectively considered to have strong export competitiveness, and 0 otherwise. Export competitiveness is measured by the market share of the main export products of sample firms and also by the information obtained in the interview analysis on the degree of product differentiation and the profitability of export products. 


\section{Appendix 5: Local subsidiaries by region and intra-firm sales}

A. Automobile

Industry average of sample firms

\begin{tabular}{|c|c|c|c|c|}
\hline & Japan & North America & Europe & Asia \\
\hline $\begin{array}{c}\text { Number of local subsidiaries } \\
\text { (Head office's equity share on local subsidiaries, \%) }\end{array}$ & -- & $\begin{array}{c}5.7 \\
(89.9)\end{array}$ & $\begin{array}{c}6.1 \\
\text { (96.5) }\end{array}$ & $\begin{array}{c}6.4 \\
\text { (66.2) }\end{array}$ \\
\hline \hline Number of production subsidiaries & 5.3 & 2.3 & 1.9 & 5.0 \\
\hline $\begin{array}{c}\text { Foreign sales in region / Consolidated sales } \\
\text { (\% of foreign sales in region to toal foreign sales) }\end{array}$ & 50.8 & $\begin{array}{c}19.1 \\
(34.1)\end{array}$ & $\begin{array}{c}13.5 \\
(23.6)\end{array}$ & $\begin{array}{c}14.9 \\
(39.2)\end{array}$ \\
\hline Intra-firm sales in region / Consolidated sales & 20.1 & 0.4 & 0.6 & 1.7 \\
\hline Intra-firm sales in region / Foreign sales in region & 52.4 & 2.3 & 3.7 & 31.0 \\
\hline
\end{tabular}

B. Electronics machinery

Industry average of sample firms

\begin{tabular}{|c|c|c|c|c|}
\hline & Japan & North America & Europe & Asia \\
\hline $\begin{array}{c}\text { Number of local subsidiaries } \\
\text { (Head office's equity share on local subsidiaries, \%) }\end{array}$ & -- & $\begin{array}{c}11.6 \\
\text { (98.9) }\end{array}$ & $\begin{array}{c}9.0 \\
\text { (95.2) }\end{array}$ & $\begin{array}{c}18.9 \\
(89.9)\end{array}$ \\
\hline \hline Number of production subsidiaries & 16.6 & 1.4 & 1.2 & 11.2 \\
\hline $\begin{array}{c}\text { Foreign sales in region / Consolidated sales } \\
\text { (\% of foreign sales in region to toal foreign sales) }\end{array}$ & 54.1 & $\begin{array}{c}16.9 \\
(35.0)\end{array}$ & $\begin{array}{c}15.8 \\
(33.4)\end{array}$ & $\begin{array}{c}14.0 \\
(32.3)\end{array}$ \\
\hline Intra-firm sales in region / Consolidated sales & 27.8 & 0.9 & 0.3 & 11.3 \\
\hline Intra-firm sales in region / Foreign sales in region & 81.1 & 5.3 & 3.0 & 79.4 \\
\hline
\end{tabular}

C. Machinery

Industry average of sample firms

\begin{tabular}{|c|c|c|c|c|}
\hline & Japan & North America & Europe & Asia \\
\hline $\begin{array}{c}\text { Number of local subsidiaries } \\
\text { (Head office's equity share on local subsidiaries, \%) }\end{array}$ & -- & $\begin{array}{c}4.3 \\
(92.6)\end{array}$ & $\begin{array}{c}5.0 \\
(92.5)\end{array}$ & $\begin{array}{c}6.0 \\
(78.8)\end{array}$ \\
\hline \hline Number of production subsidiaries & 5.0 & 2.3 & 1.7 & 3.0 \\
\hline $\begin{array}{c}\text { Foreign sales in region / Consolidated sales } \\
\text { (\% of foreign sales in region to toal foreign sales) }\end{array}$ & 49.2 & $\begin{array}{c}15.1 \\
(28.4)\end{array}$ & $\begin{array}{c}15.6 \\
(30.8)\end{array}$ & $\begin{array}{c}19.9 \\
(40.7)\end{array}$ \\
\hline Intra-firm sales in region / Consolidated sales & 24.9 & 0.7 & 0.5 & 0.8 \\
\hline Intra-firm sales in region / Foreign sales in region & 52.1 & 4.0 & 3.1 & 4.2 \\
\hline
\end{tabular}

D. Electronic components

Industry average of sample firms

\begin{tabular}{|c|c|c|c|c|}
\hline & Japan & North America & Europe & Asia \\
\hline $\begin{array}{c}\text { Number of local subsidiaries } \\
\text { (Head office's equity share on local subsidiaries, \%) }\end{array}$ & -- & $\begin{array}{c}6.8 \\
(98.8)\end{array}$ & $\begin{array}{c}5.3 \\
(100.0)\end{array}$ & $\begin{array}{c}22.3 \\
(94.2)\end{array}$ \\
\hline \hline Number of production subsidiaries & 9.8 & 1.5 & 1.5 & 7.8 \\
\hline $\begin{array}{c}\text { Foreign sales in region / Consolidated sales } \\
\text { (\% of foreign sales in region to toal foreign sales) }\end{array}$ & 37.8 & $\begin{array}{c}13.5 \\
(21.9)\end{array}$ & $\begin{array}{c}14.1 \\
(22.7)\end{array}$ & $\begin{array}{c}33.9 \\
(54.4)\end{array}$ \\
\hline Intra-firm sales in region / Consolidated sales & 43.9 & 0.7 & 2.6 & 24.6 \\
\hline Intra-firm sales in region / Foreign sales in region & 118.2 & 5.0 & 12.2 & 76.2 \\
\hline
\end{tabular}

1) We calculated "Number of local subsidiaries" as the number of "consolidated subsidiaries" and "companies accounted for using the equity method" in the company's financial statement.

2) "North America" includes the US, Canada, and Mexico. "Europe" includes countries in the Euro area and the UK. "Asia" includes China, Hong Kong, Taiwan, South Korea, Philipines, Singapore, Thailand, Malysia, and Indonesia.

Source: Financial statements of sample firms immediately before the interviews (FY2006 or FY2007) 